\title{
Voedselsysteeminnovatie
}

\section{Kansen voor een duurzamer en gezonder Nederland}

Anne-Charlotte Hoes | juli 2018

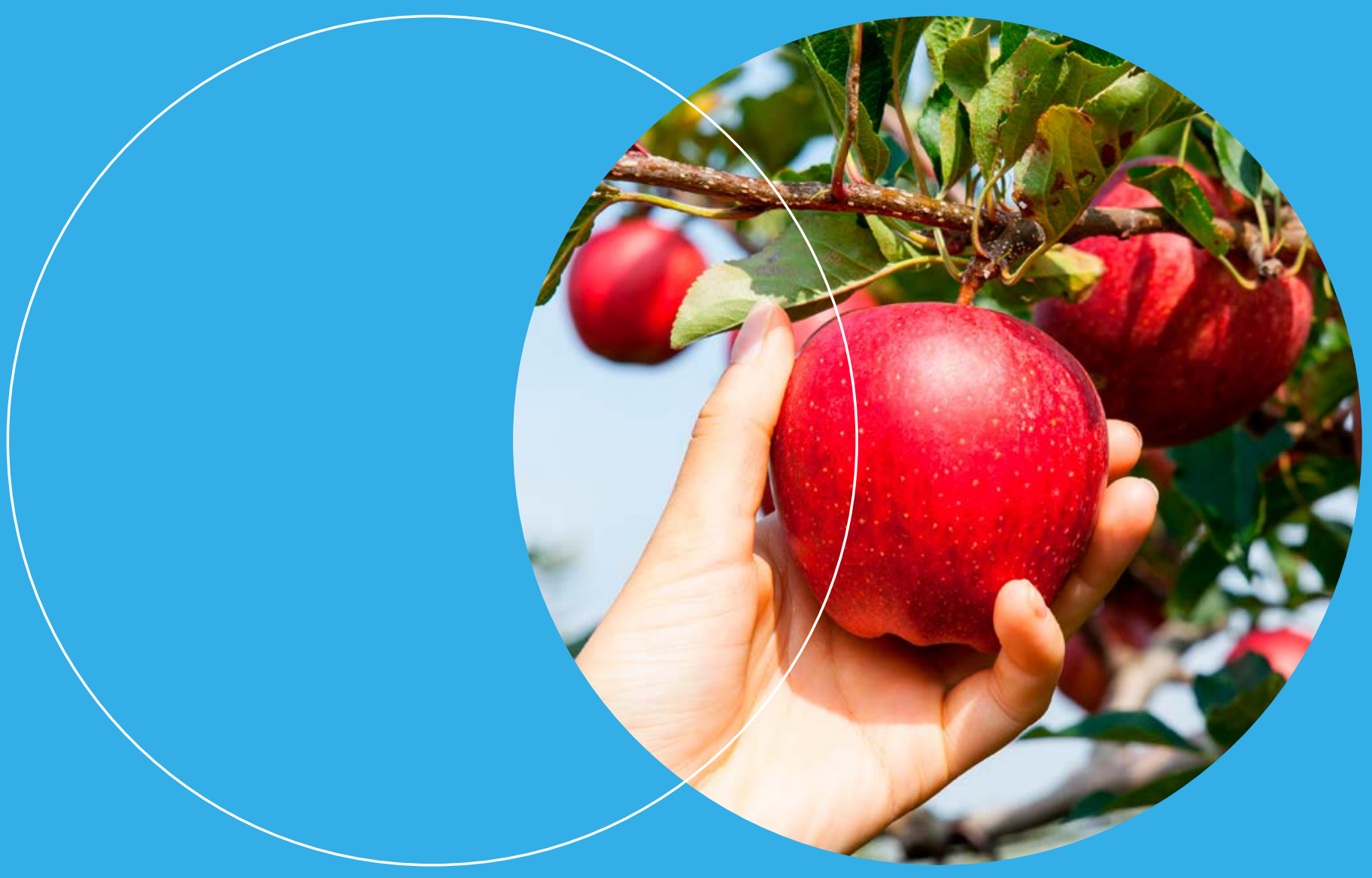

(1) Een duurzamer en gezonder voedselsysteem

(2) Opgaven voor een duurzamer en gezonder voedselsysteem

(3) Vijf richtingen voor voedselsysteeminnovatie

(4) Systeeminnovatiebarrières

5 Voedselsysteeminnovaties kansen in Nederland

6) Referenties 


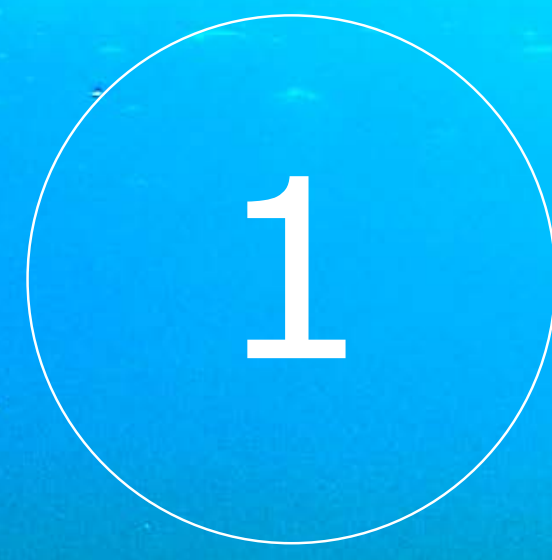

\section{Een duurzamer en gezonder voedselsysteem}

Met de Duurzame Ontwikkelingsdoelstellingen (SDG's - Sustainable Development Goals) werken landen in gezamenlijkheid aan een betere toekomst. Een meerderheid van de SDG's heeft betrekking op ons voedselsysteem. Voor velen is evident dat de doelen 'beëindig honger', 'bescherm de zeeën' en 'duurzame consumptie en productie' over ons voedselsysteem gaan. Echter, meer indirect zijn ook doelen zoals 'gezondheid en welzijn', 'schoon drinkwater', 'minder ongelijkheid', 'veilige en duurzame steden', 'klimaatverandering aanpakken' en 'behoud van biodiversiteit' afhankelijk van een goed functionerend voedselsysteem.

Voedselsysteem: een complex netwerk van mensen, natuur en technologie

Het woord 'voedselsysteem' benadrukt dat voedsel veel omvat en niet geïsoleerd beschouwd kan worden (WRR, 2014). Naast consumenten boeren, toeleveranciers, industrie, retail en horeca omvat het voedselsysteem een netwerk van bedrijven (financiële instellingen, veterinaire diensten en kassenbouwers), overheden (van gemeentes tot Europa), andere organisaties (kennisinstellingen, onderwijs, ngo's, CSO's), andere actoren (buren en burgers), internationale afspraken, leefomgeving (bodem, water, lucht en biodiversiteit) en technologieën (ICT, fabrieken, infrastructuur en machines) (Berkum et al., 2018; HLPE, 2017). Kortom, het omvat een sociaal-technologisch systeem van actoren en dingen die met elkaar interacteren. Figuur 1 biedt een visualisering van het voedselsysteem waarbij expliciet aandacht wordt gegeven aan de verbondenheid tussen het voedselsysteem en het biologische, economische, sociale, politieke en gezondheidssysteem (www.nourishlife.org, Food System Map, 2014).

Overzicht van de uitdagingen voor voedselsysteeminnovaties Deze publicatie is geschreven in opdracht van het ministerie van Landbouw, Natuur en Voedselkwaliteit en biedt een beknopte samenvatting van de huidige voedselsysteeminnovatieopgave, oplossingsrichtingen, innovatiebarrières en kansen. Een eerdere versie van dit manuscript is gebruikt als discussiestuk voor de expert workshop van het SKIP (Strategisch Kennis en Innovatieprogramma) Team Voedsel.
Een duurzamer en gezonder voedselsysteem

(2) Opgaven voor een duurzamer en gezonder voedselsysteem

(3) Vijf richtingen voor voedselsysteeminnovatie

(4) Systeeminnovatiebarrières

(5) Voedselsysteeminnovaties kansen in Nederland

(6) Referenties 


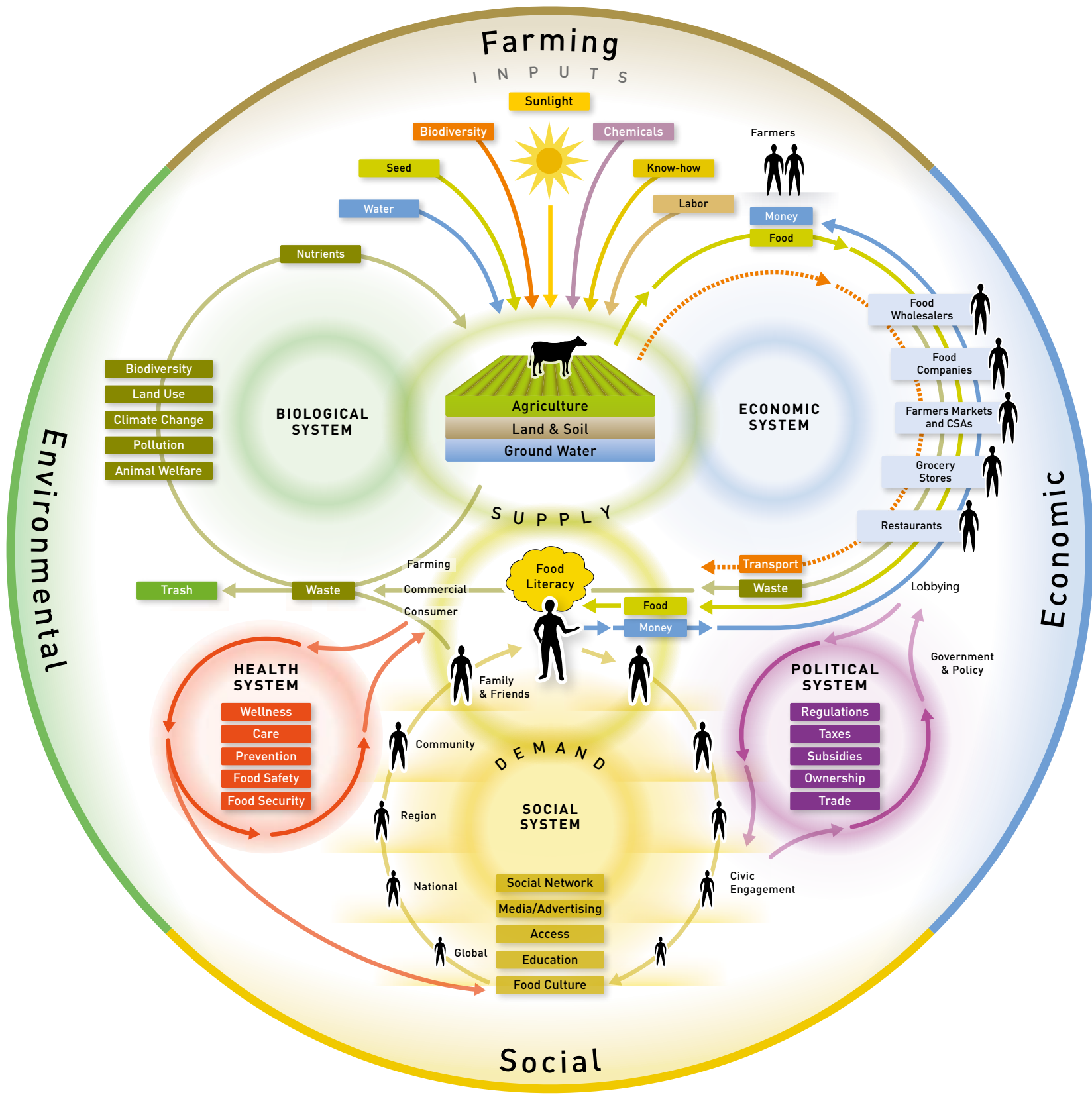

(1) Een duurzamer en gezonder voedselsysteem

(2) Opgaven voor een duurzamer en gezonder voedselsysteem

(3) Vijf richtingen voor voedselsysteem innovatie

(4) Systeeminnovatiebarrières

(5) Voedselsysteeminnovaties kansen in Nederland

(6) Referenties 



\section{Internationale ontwikkelingen}

Uitdagingen Nederlands voedelsysteem

houdbaarheid
kwaliteit
eit

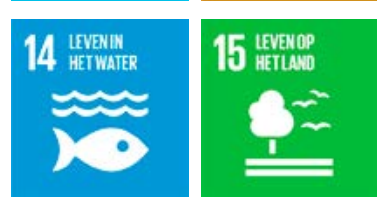

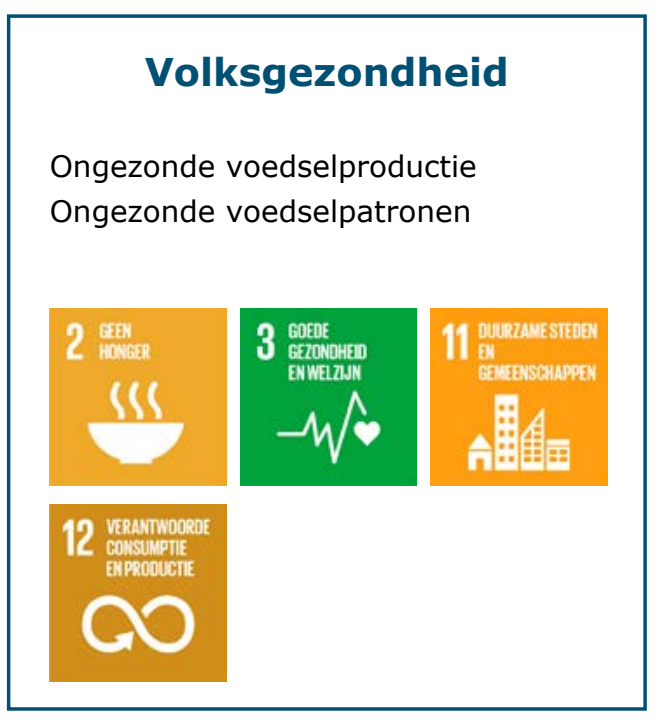

(1) Een duurzamer en gezonder voedselsysteem

(2) Opgaven voor een duurzamer en gezonder voedselsysteem

Ecologische houdbaarheid Volksgezondheid Robuustheid

(3) Vijf richtingen voor voedselsysteeminnovatie

Levensvatbare bedrijven Sociale acceptatie
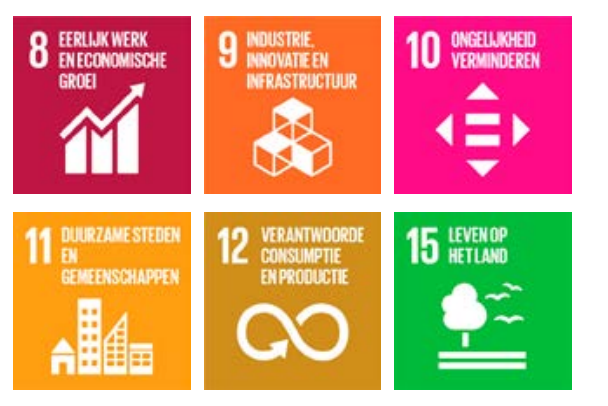

(4) Systeeminnovatiebarrières

(5) Voedselsysteeminnovaties kansen in Nederland

(6) Referenties

Figuur 2: Nederlandse opgaven voor een duurzamer en gezonder voedselsysteem 


\section{Ecologische houdbaarheid}

Huidige Nederlandse uitdagingen

\section{Uitstoot broeikasgassen}

- De Nederlandse landbouw is verantwoordelijk voor $26 \mathrm{Mton} \mathrm{CO}_{2}-$ equivalenten, wat $14 \%$ van de totale uitstoot in Nederland behelst (RVO, 2016).

- De veehouderij stoot de meeste $\mathrm{CO}_{2}$-equivalenten uit, waarbij methaan de belangrijkste bron van broeikasgas is. Andere bronnen zijn lachgas en energieverbruik. Methaan komt vrij via het verteringssysteem van rundvee en opgeslagen mest.

- Lachgas komt vooral vrij uit de bodem bij bemesting

- $\mathrm{CO}_{2}$ komt vooral vrij door verbruik van energie (gas, elektriciteit, diesel) bij bijvoorbeeld de glastuinbouw (WRR, 2014; RVO, 2016).

- Daarnaast komen $\mathrm{CO}_{2}$-equivalenten vrij bij de verwerking tot en met de consumptie en afvalverwerking van voedsel.

\section{Water- \& bodemkwaliteit}

- Uitspoeling van meststoffen zoals nitraat (RIVM, 2016) en gewasbeschermingsmiddelen (Snoo en Vijver 2012) zorgen voor vervuiling van het Nederlandse grond-, oppervlakte- en drinkwater. ${ }^{1}$

- 'De ecologische kwaliteit van het oppervlaktewater voldoet nog bijna nergens aan de doelen van de Kaderrichtlijn Water (Faber, 2013)' (WRR, 2014, p.71).

- Daarnaast verzuurt de bodem en wordt het bodemleven aangetast (Kemmers, 2011).

- Verzilting van de bodem door polders en drinkwaterwinning.

\section{Verlies biodiversiteit}

- In Nederland zijn sinds 1900 minstens 614 plant- en diersoorten verdwenen (LNV, 2010).

- In Nederland krijgen vele planten en dierensoorten niet de ruimte of het geschikte milieu om te groeien. Dit komt onder andere door het verbouwen van monoculturen (onder andere Engels raaigras), verstoring door grondbewerking en een ongunstig milieu door de aanwezigheid van meststoffen en gewasbeschermingsmiddelen.

1 Wel is de afgelopen decennia vooruitgang geboekt in het terugdringen van uitspoeling van milieubelastende stoffen (LMM, 2017; WRR, 2014). Het zuidelijk zandgebied blijft echter een probleemgebied en dit stagneert (Dam, van, 2017).

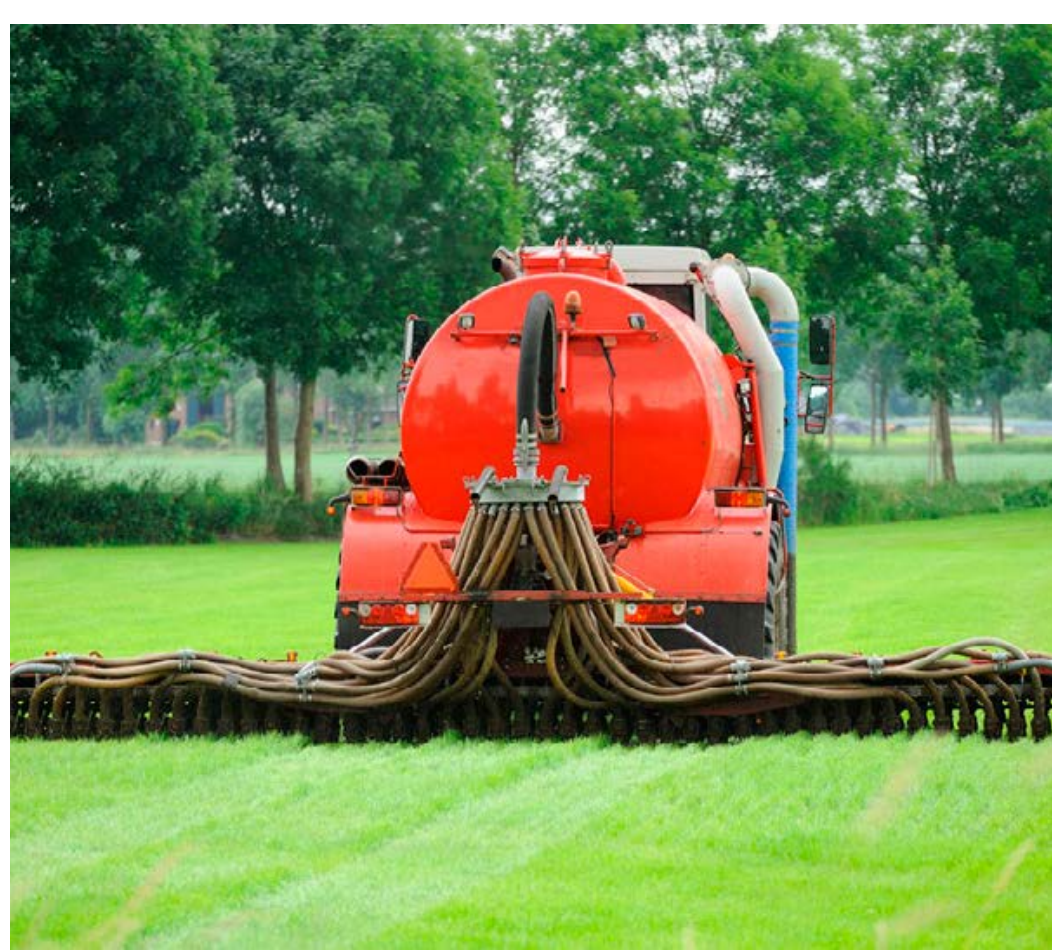

- Door mesttoediening treedt eutrofiëring in het water en de bodem op (vergroting van de voedselrijkdom), wat een bedreiging vormt voor voedselarme natuurtypen zoals schraalgraslanden en op het oppervlaktewater de groei van onder andere blauwalgen stimuleert (clo.nl).

- In het buitenland worden (natuur)gronden bewerkt voor onder andere ruwvoer voor de Nederlandse markt. Vijfentachtig procent van het grondgebruik dat nodig is om de Nederlanders van hun voedsel, hout en papier te voorzien ligt buiten de Nederlandse grenzen. Het totale landoppervlakte dat wordt gebruikt is drie keer zo groot als Nederland (WRR, 2014).

- Daarnaast tast de visserij de biodiversiteit van de zeeën aan. 'Naar schatting wordt ongeveer de helft van de visvoorraden reeds volledig benut. Bij de meeste van de top tien gevangen vissoorten is sprake van overexploitatie. Die is een gevolg van de grootschalige visserij, die de zeebodem en daarmee de habitat van soorten aantast en de bijvangst als afval overboord zet' (WRR, 2014, p. 46).
Een duurzamer en gezonder voedselsysteem

(2) Opgaven voor een duurzamer en gezonder voedselsysteem

Ecologische houdbaarheid Volksgezondheid Robuustheid

(3) Vijf richtingen voo voedselsysteeminnovatie

(4) Systeeminnovatiebarrières

(5) Voedselsysteeminnovaties kansen in Nederland

(6) Referenties 
- Hoewel de hoeveelheid milieuvervuiling gestaag afneemt (zoals de hoeveelheid meststoffen die worden toegediend), daalt de biodiversiteit in Nederland nog steeds (WRR, 2014).

Internationale ontwikkelingen

- De wereldwijde toename van de voedselvraag zal de voedselproductie, en de wereldwijde milieudruk, verhogen (WRR, 2014).

- Voedselproductie zal wereldwijd efficiënter worden en verder industrialiseren. Het merendeel van de mondiale voedselproductie wordt geproduceerd door kleinschalige boerenbedrijven met minder dan 2 ha grond. Opschaling en toepassing van opgedane kennis en technologieën zoals andere zaden, mest, gewasbescherming en eenvoudige ICT en monitoring dragen hieraan bij (WRR, 2014)

- Daarnaast kan klimaatverandering wereldwijd zorgen voor verwoestijning en bodemerosie, verstoring waterkringlopen en plaatselijke watertekorten, overstroming van gebieden of verzilting van de

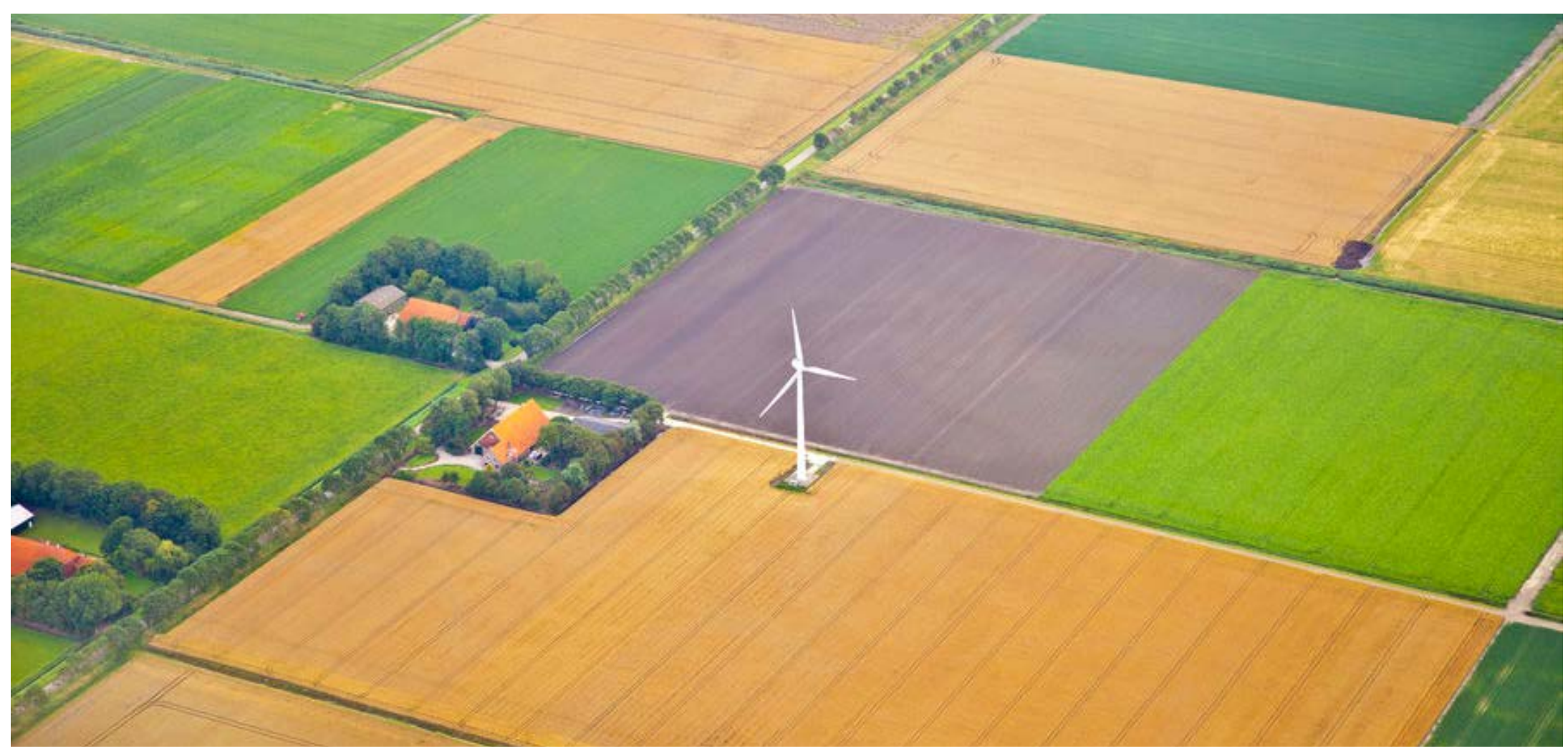

bodem door stijging van de zeespiegel, grotere kans op weersextremen, zoals droogte of hevige regenval, wat de oogsten onstabieler kan maken (WRR, 2014). Daartegenover staat dat voorheen onbetrouwbare gronden geschikt worden als landbouwgrond (WRR, 2014)
(1) Een duurzamer en gezonder voedselsysteem

2 Opgaven voor een duurzamer en gezonder voedselsysteem

Ecologische houdbaarheid

Volksgezondheid Robuustheid

(3) Vijf richtingen voor voedselsysteeminnovatie

(4) Systeeminnovatiebarrières

(5) Voedselsysteeminnovaties kansen in Nederland

(6) Referenties 


\section{Volksgezondheid}

\section{Huidige Nederlandse uitdagingen}

\section{Ongezonde voedselproductie}

- Zoönosen, ziekten die overspringen van dier op mens, vormen een bedreiging voor de volksgezondheid (WRR, 2017; Haalboom, 2017). Bekende zoönosen zijn salmonella, campylobacter en Q-koorts. De Nederlandse Q-koortsuitbraak van 2007 tot 2010 heeft het leven gekost van 74 patiënten en sommige patiënten hebben chronische Q-koorts ontwikkeld (Haalboom, 2017).

- Antibioticagebruik in de veehouderij draagt bij aan de resistentie van bacteriën tegen antibiotica. Vee-gerelateerde MRSA komt bijvoorbeeld veel voor bij Nederlandse veebedrijven: bij $88 \%$ van de onderzochte vleeskalverenbedrijven en $68 \%$ van de onderzochte varkensbedrijven (Maassen et al., 2012). Maatregelen zijn genomen om antibioticagebruik in de veehouderij tegen te gaan waardoor tussen 2009 en 2016 de verkoop is afgenomen met 64,4\% (Rijksoverheid, 2018).

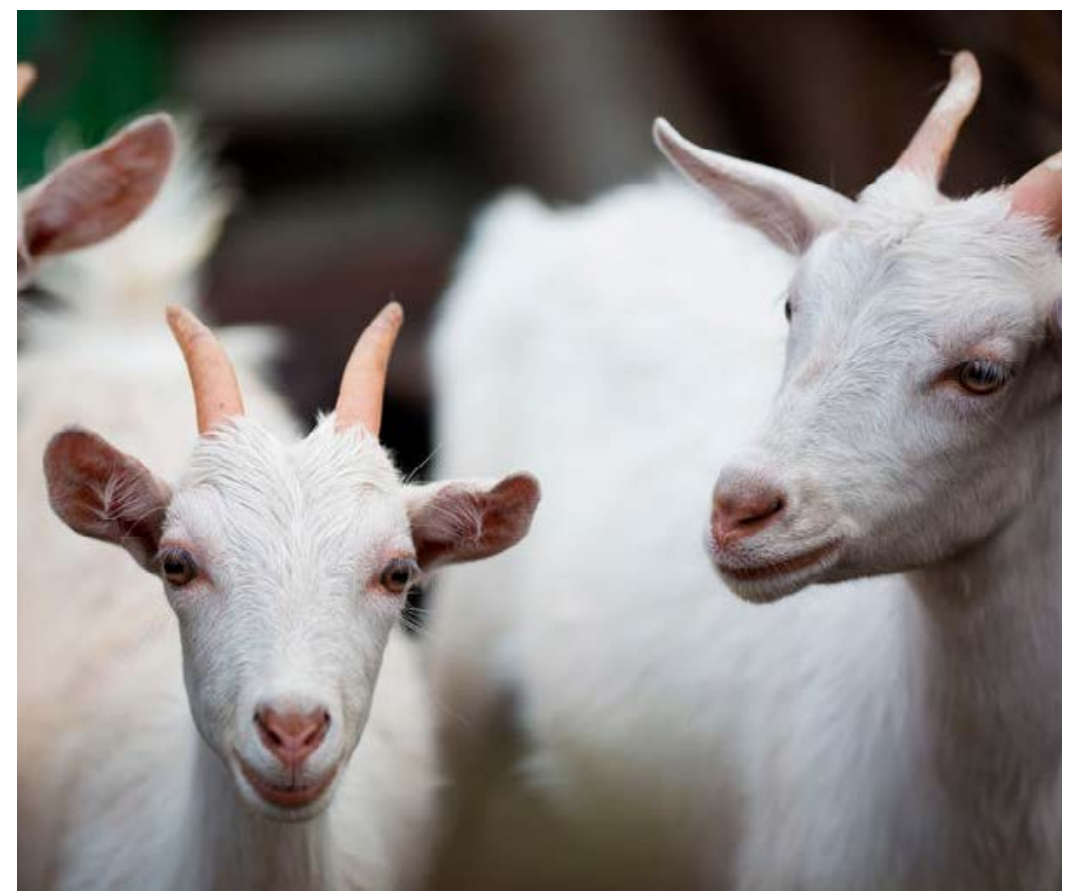

- Residuen van gewasbeschermingsmiddelen blijven een aandachtspunt maar hierin heeft Nederland de afgelopen decennia stappen gezet. Tegenwoordig wordt vooral op groente en fruit van nietEuropese landen residuen van gewasbeschermingsmiddelen aangetroffen (NVWA, 2013). In deze landen vinden ook vaker incidenten plaats waarbij telers te veel bloot worden gesteld aan gewasbeschermingsmiddelen.

- Daarnaast stoten veehouderijbedrijven fijnstof en ammoniak uit die in verband worden gebracht met afname van de longfunctie (Maassen et al., 2016). Het Besluit emissiearme huisvesting van 2015 helpt in het terugdringen van de uitstoot van ammoniak (wetten.overheid.nl/BWBR0036748/2017-01-01).

\section{Ongezond voedingspatroon}

- Nederlanders eten te weinig groente en fruit. 'Slechts 1 tot 14 procent (afhankelijk van de leeftijdsgroep) van de bevolking eet voldoende groente en fruit (WRR, 2014 p. 72).

- De afgelopen 50 jaar zijn we steeds meer bewerkt voedsel gaan eten. In bewerkt voedsel zit vaak te veel suiker, slechte vetten en zout (Vink en Boezeman, 2018; WRR, 2014).

- Een slecht eetpatroon en onvoldoende beweging kunnen leiden tot het metaboolsyndroom. Het metaboolsyndroom verhoogt het risico op diabetes type 2 en hart- en vaatziekten. Het is aanwezig als de persoon in kwestie minstens drie van de volgende kenmerken heeft:

- grote buikomtrek

- hoge bloeddruk

- een laag HDL-cholesterolgehalte en

- een verhoogd glucose- en/of trigyceridengehalte in het bloed. Het metaboolsyndroom is waarschijnlijk in Nederland aanwezig bij $34 \%$ van de mannen en $24 \%$ van de vrouwen in de leeftijd van 30-70 (RIVM, 2012).

- De helft van de Nederlanders is te zwaar en $14 \%$ heeft obesitas. Jaarlijks worden ongeveer 40.000 mensen ziek als gevolg van overgewicht (hierbij gaat het om diabetes, hart- en vaatziekten en/ of kanker) en circa 7.000 mensen overlijden voortijdig. Ook worden ongeveer 40.000 Nederlanders ziek en gaan ongeveer 13.000 mensen voortijdig dood omdat we te veel verzadigde vetzuren en transvetzuren eten en te weinig vis, groente en fruit consumeren (WRR, 2014).
(1) Een duurzamer en gezonder voedselsysteem

2 Opgaven voor een duurzamer en gezonder voedselsysteem

Ecologische houdbaarheid

Volksgezondheid Robuustheid

(3) Vijf richtingen voo voedselsysteeminnovatie

(4) Systeeminnovatiebarrières

(5) Voedselsysteeminnovaties kansen in Nederland

(6) Referenties 


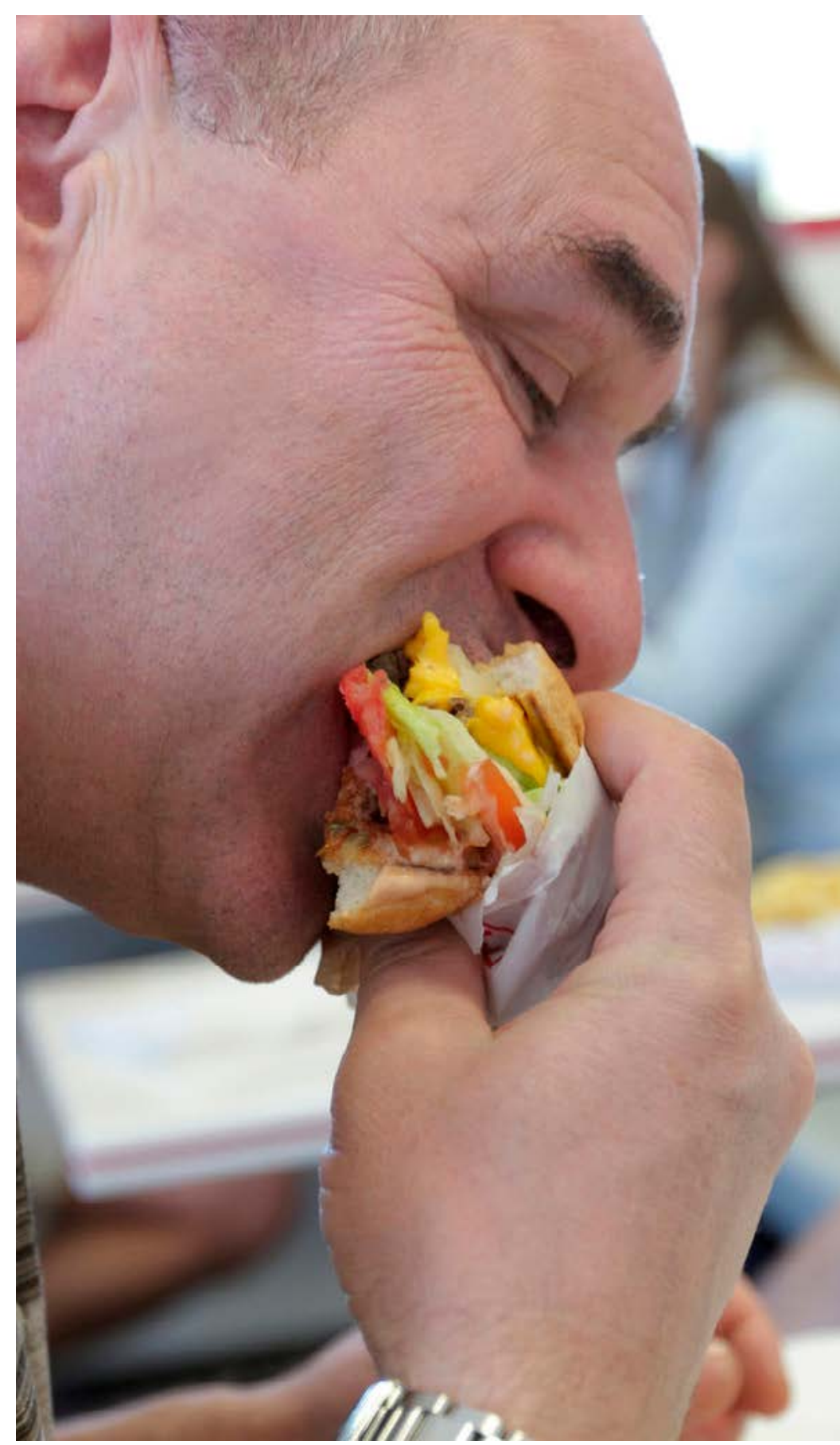

- Er is nog veel onbekend over de relatie tussen voeding en gezondheid. Men vindt alleen correlaties tussen voedingspatronen en kenmerken zoals gewicht. Het trekken van overtuigende oorzaakgevolgrelaties tussen het nuttigen van bepaald voedsel en gezondheidstoestand is nog lastig.

- Voedselveiligheid en hygiëne blijft een punt van aandacht. In 2009 kregen bijvoorbeeld 650.000 mensen last van infecties door voeding (onder andere salmonella) (WRR; 2014)

- Voeding heeft een marginale positie in de gezondheidszorg (WRR 2014).

- Door de onzekerheid over (on)gezonde voeding is er een toename van het aantal mensen die voedingsadvies geven zonder wetenschappelijke basis. Sommige van deze ervaringsdeskundige kunnen handvatten bieden aan consumenten. Echter, andere pleiten voor voedingspatronen die niet passen in het huidige Nationale voedingsadvies (Peters, 2013).

- Een extreme tegenbeweging is de aandoening orthorexia nervosa - een eetstoornis waarbij iemand lijdt aan een preoccupatie met of zelfs een obsessie heeft voor gezond eten, wat kan leiden tot ondervoeding.

Internationale ontwikkelingen

- Internationale handel verhoogt het risico van zoönose (WRR, 2014).

- Intensivering van wereldwijde voedselproductie verhoogt het gebruik van antibiotica en gewasbeschermingsmiddelen in landen waar de controle en handhaving van gebruik nog niet optimaal is.

- $\mathrm{Er}$ is een opkomende vraag naar 'gemaksvoeding' (samengesteld en 'ready to eat') die vaak veel zout, suiker en vet bevat.

- Er is een ambitie bij diverse retail- en brand owners om hun businessmodel te veranderen en 'gezondheid' te bieden aan hun klanten.

- Er is steeds meer aandacht voor en vraag naar gezonde voeding.
(1) Een duurzamer en gezonde voedselsysteem

(2) Opgaven voor een duurzamer en gezonder voedselsysteem

Ecologische houdbaarheid

Volksgezondheid Robuustheid

(3) Vijf richtingen voo voedselsysteeminnovatie

(4) Systeeminnovatiebarrières

(5) Voedselsysteeminnovaties kansen in Nederland

(6) Referenties 


\section{Robuustheid}

Huidige Nederlandse uitdagingen

\section{Levensvatbare bedrijven}

- Bedrijven zijn nodig om ons voedsel te produceren (boeren), verwerken (fabrieken) en distribueren (retail). Een deel van de agrarische ondernemingen staat echter onder druk (Vink en Boezeman, 2018).

- Door grote internationale concurrentie zijn de winstmarges in Nederland laag. Onder andere vanwege dure grond, arbeid, materiaal en wettelijke eisen (zoals mestafvoer, waterzuiveringsplicht en dierenwelzijnseisen). Dit maakt het lastig om tegenvallers op te vangen en om te gaan met kleine schommelingen in de markt, die toenemen door de toegankelijke wereldhandel. Dit resulteert in een bedrijfsmodelstrategie van lagekostprijs. Dit dwarsboomt het investeren in bijvoorbeeld milieu- en diervriendelijke technologieën. Dit verklaart ook waarom het aantal agrarische bedrijven in Nederland gestaag daalt en bedrijfsopvolging lastig te vinden is. In de varkenshouderij halveert bijvoorbeeld het aantal bedrijven iedere tien jaar (Hoste, 2017; Agrimatie.nl).

- De bodemkwaliteit in sommige delen van Nederland staat onder druk door intensieve bouwplannen, het gebruik van zware machines bij met name de oogstwerkzaamheden en het tekort aan organische stof die aan de bodem wordt toegevoegd. Met name de bodemgezondheid en -structuur en het bodemleven komen hierdoor in gevaar (LEB, 2015). Daarnaast is er bodemdaling in het veenweidegebied en verzilting van landbouwgronden door de laaggelegen polders met lage waterstand waardoor de kweldruk toeneemt.

- Sommige provincies eisen extra voorwaarden bij bedrijfsuitbreiding (bzv.brabant.nl) en afnemers extra leveringseisen om tegemoet te komen aan maatschappelijke onrust (Reijs, 2018; in bijlage 1 voorbeelden).

\section{Sociale acceptatie}

- Het lokaal protest tegen megastallen, onder andere vanwege stank-, gezondheids- en verkeersoverlast, groeit (Os et al., 2013; Termeer et al., 2013). De roep om een leefbaar buitengebied neemt toe (Fresco en Poppe, 2016). Vooral in Brabant is na de

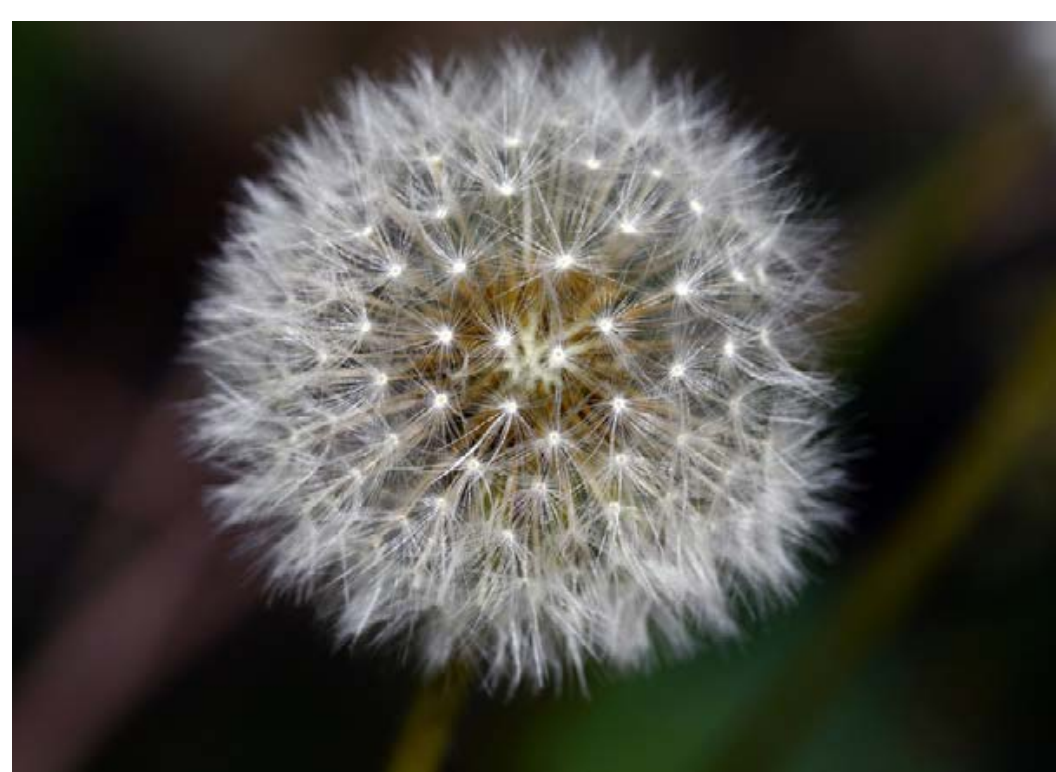

Q-koortsuitbraak het grootschalig houden van dieren meer een gezondheidsissue geworden dan een milieudiscussie (Termeer et al., 2013).

- Ook groeit het nationale protest tegen kiloknallers, plofkippen, stalmelk en varkensleed (wakkerdier.nl). Steeds meer mensen lijken de praktijk van dieren houden voor voedsel een ethisch problematische situatie te vinden.

- Sociale acceptatie van het voedselsysteem heeft ook te maken met het vertrouwen dat men heeft in het voedselproductiesysteem (Onwezen et al., 2016) en het vertrouwen dat voedselveiligheid gegarandeerd is (WRR, 2014).

Internationale ontwikkelingen

- Het Nederlandse voedselsysteem is afhankelijk van goedkope buitenlandse inputstromen (onder andere ruwvoer en fosfaat voor kunstmest). Het is onzeker of Nederland in de toekomst nog steeds relatief goedkoop (ruw)voer en fosfaat kan importeren uit het buitenland (Berkhout et al., 2018; WRR, 2014).

- Het Nederlandse voedselsysteem is afhankelijk van een exportmarkt. Het is onzeker of deze landen in de toekomst ook afhankelijk zijn van de Nederlandse producten of dat ze hun eigen voedselvoorziening verbeteren (Berkhout et al., 2018).
Een duurzamer en gezonder voedselsysteem

(2) Opgaven voor een duurzamer en gezonder voedselsysteem

Ecologische houdbaarheid Volksgezondheid Robuustheid

(3) Vijf richtingen voo voedselsysteeminnovatie

(4) Systeeminnovatiebarrières

5 Voedselsysteeminnovaties kansen in Nederland

6 Referenties 


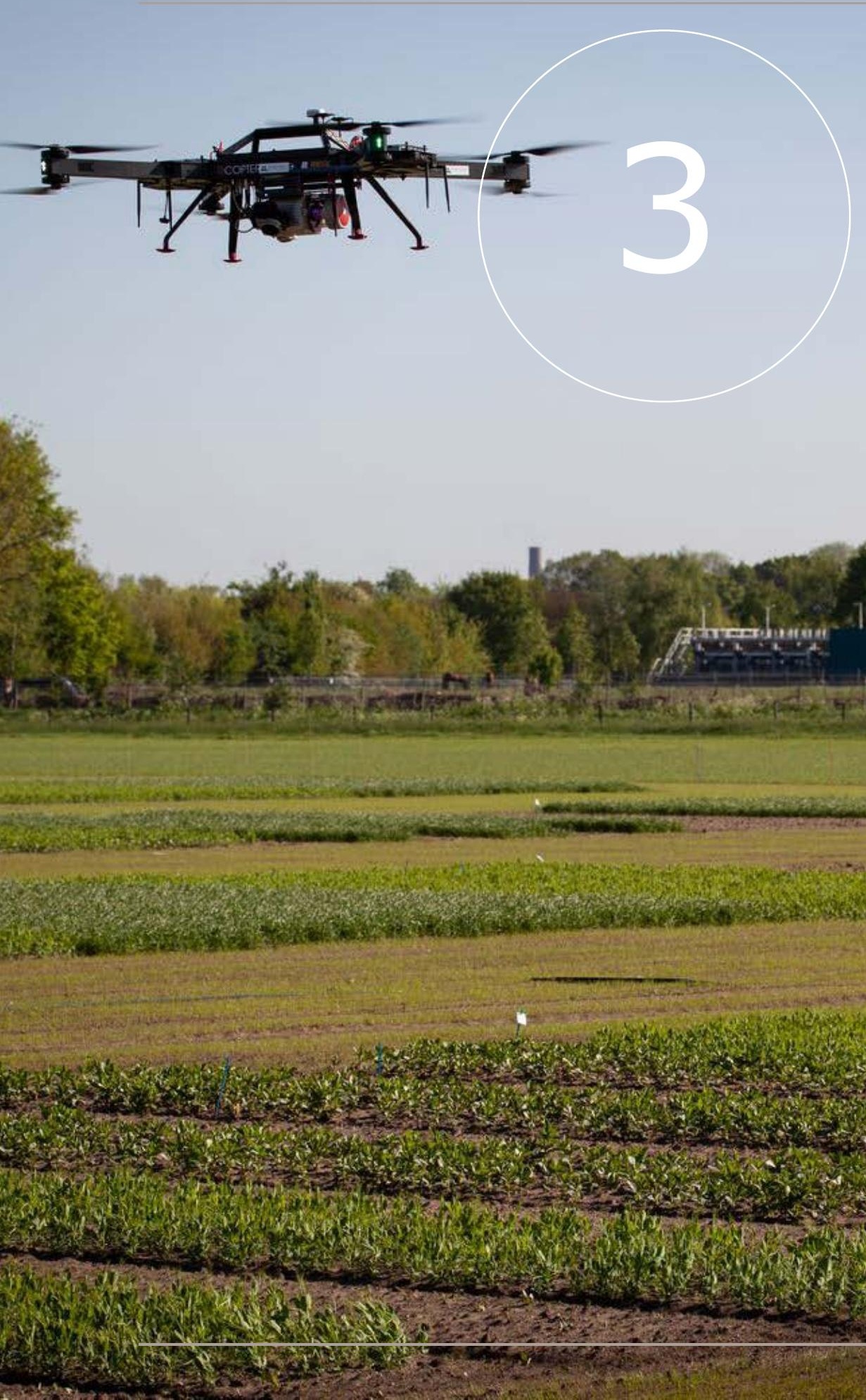

\section{Vijf richtingen voor voedselsysteeminnovatie}

In recente Nederlandse publicaties wordt gepleit voor een ontwikkeling die resulteert in een duurzamer, betaalbaar, eerlijk, gezond betrouwbaar en hoogwaardig voedselsysteem (Fresco en Poppe, 2016; Kampers en Fresco, 2017; Muilwijk et al., 2018; RLI, 2018 Vink en Boezeman, 2018). Alhoewel de urgentie voor verandering wordt gedeeld, is er geen consensus over welke voedselinnovaties het meest wenselijk zijn (Dagevos, 2017; Jong, de, 2018). Deze publicatie vat de wenkende voedselinnovatieperspectieven samen tot vijf voedselsysteeminnovatierichtingen:

1 Duurzame productie

2 Plantaardige en nieuwe eiwitten

3 Circulaire economie

4 Gezonde consumptie

5 Veerkrachtig

Nieuwe sleuteltechnologieën, zoals digitalisering, robotisering en big data, spelen een belangrijke rol bij de opkomst en ontwikkeling van deze systeeminnovatierichtingen (ofwel enabling technologies). Ook is er vernieuwing in aanpalende domeinen, zoals landschap en natuur. Deze domeinen zijn buiten beschouwing gehouden omdat deze publicatie zich richt op het voedselsysteeminnovaties.

\section{Duurzame Productie}

Voedselinnovaties zoals precisielandbouw, voedseltransparantie, biologische landbouw, hightechstallen en -kassen en genetica kunnen bijdragen aan een voedselproductie die dier-, mens- en milieuvriendelijker is.

Bij precisielandbouw worden GPS, sensoren, ICT en robotisering ingezet om teelten, bodem en vee nauwkeurig en gepersonaliseerd te verzorgen. In de teelt kan straks per vierkante meter of per plant gestuurd worden in plaats van op perceelniveau. Dit maakt geïntegreerde gewasbescherming (IPM) en precisiebemesting
(1) Een duurzamer en gezonde voedselsysteem

(2) Opgaven voor een duurzamer en gezonder voedselsysteem

3 Vijf richtingen voor voedselsysteeminnovatie

Duurzame Productie Plantaardige en nieuwe eiwitten

Circulaire economie Gezonde consumptie Veerkrachtig

(4) Systeeminnovatiebarrières

5 Voedselsysteeminnovaties kansen in Nederland

(6) Referenties 
mogelijk waardoor een schonere bodem ontstaat. In de veehouderij lopen innovaties op het gebied van dier 'smartwatches', slimme voer- en melksystemen en videomonitoring. Deze technieken kunnen veehouders inzetten om diermanagement toe te passen in plaats van kudde-management. Daarbij maken sensoren, digitale databases en blockchaintechnologie het mogelijk om in de toekomst een grote mate van voedseltransparantie te bieden. Deze transparantie geeft inzichten in hoe duurzaam de landbouwpraktijk is en stelt afnemers in staat om duurzamere alternatieven te selecteren en duurzaamheidsvoorwaarden te controleren. Keurmerken en ketenafspraken spelen daar een belangrijke rol bij.

Een andere ontwikkelingsrichting is de biologische landbouw en meer of minder radicale vormen van natuurinclusieve landbouw c.q. voedselsystemen. Het gemeenschappelijke kenmerk van deze bedrijven en ontwikkelrichting is dat het bedrijfsmanagement en teeltsystemen gericht zijn op het ondersteunen van biologische en ecologische processen in en boven de grond. Een voorbeeld hiervan is permacultuur. Er wordt geen gebruikgemaakt van synthetische gewasbescherming en kunstmest.

Daarnaast zijn er innovaties in landbouwwerktuigen en hightechstallen en -kassen die steeds slimmer en energie- en uitstootneutraal worden. En ook op het gebied van genetica (CRISPR-cas9) worden stappen gezet waardoor gemakkelijker robuuste planten en dieren kunnen worden ontwikkeld (Fresco en Poppe, 2016).

\section{Plantaardige en nieuwe eiwitten}

Een overgang naar alternatieve eiwitbronnen, zoals peulvruchten, insecten, zeewier, algen en andere organismes, heeft een positief effect op de milieudruk en waarschijnlijk op de volksgezondheid (Kampers en Fresco, 2017). De productie van vlees, zuivel en eieren vereist veel plantaardig materiaal en hiervoor is veel landbouwgrond en water nodig. Vooral de productie van rundvlees is milieubelastend. Snelgroeiende kippen zetten efficiënter plantaardige eiwitten om in dierlijke eiwitten dan runderen. De productie van kippenvlees is daardoor relatief minder milieubelastend (Bakker en Dagevos 2010; Dekker, 2012). Een eiwittransitie vergt naast een overgang van dierlijke naar alternatieve eiwitproductie met een hoge voedingswaarde ook om radicale aanpassingen in het voedingspatroon van consumenten (RLI, 2018).

\section{Circulaire economie}

De circulaire economie staat voor een economisch systeem (zoals het voedselsysteem) waarin maximaal gebruik wordt gemaakt van nutriënten en grondstoffen. Denk bijvoorbeeld aan reststoffen volledig hergebruiken en geen eindige grondstoffen uitputten. Voor het voedselsysteem gaat het dan onder andere om het radicaal terugdringen van voedselverspilling en het overstappen naar efficiënter voedsel (zoals de eiwittransitie). Maar ook het sluiten van voedselproductie-, industriële- en consumptiekringlopen en gebruikmaken van biobased verpakkingsmaterialen vallen hieronder Daarbij is het belangrijk dat producten en reststromen zo hoogwaardig mogelijk worden verwerkt. Dit wordt ook wel vierkantswaardering en cascadering genoemd, waarbij verspilling wordt voorkomen door elk deel van een product tot waarde te brengen. Nieuwe technieken op het gebied van bewaarsystemen, drogen en het scheiden van inhoudstoffen en biobased chemicaliën maken het mogelijk om in de toekomst nog efficiënter en effectiever hernieuwbare grondstoffen te benutten (WUR, 2012). Andere innovaties die bijdragen aan een circulaire economie zijn korteketeninitiatieven en stadslandbouw waarbij braakliggende gronden (moestuinprojecten) en lege panden in stedelijk gebieden (vertical farming) in productie worden genomen.

\section{Gezonde consumptie}

Voeding speelt een belangrijke rol in de gezondheid van mensen. Big data van persoonlijke voedingsconsumptie, nutriënten en gezondheid helpen om meer inzicht te krijgen in de relatie tussen voeding en gezondheid. Dit biedt de mogelijkheid om gerichter voedingsadvies te kunnen geven en om gezondere producten te ontwikkelen die passen bij de levensstijl van mensen. Een Europese (digitaal) onderzoeksplatform met gestandaardiseerde methode om bijvoorbeeld accuraat voedselinname te monitoren kan hierin helpen (www.fnhri.eu). Nu
(1) Een duurzamer en gezonder voedselsysteem

(2) Opgaven voor een duurzamer en gezonder voedselsysteem

Vijf richtingen voor voedselsysteeminnovatie

Duurzame Productie

Plantaardige en nieuwe eiwitten

Circulaire economie Gezonde consumptie Veerkrachtig

(4) Systeeminnovatiebarrières

5 Voedselsysteeminnovaties kansen in Nederlan 
komen er ook al bedrijven met gezondheidsbevorderende voedingsproducten op de markt, onder andere in de zuivel. Daarnaast maken geno- en fenotypische analysemethodieken en sensoren het mogelijk om in de toekomst gezondheid van personen continu te monitoren en zelfs gepersonaliseerd voedingsadvies te geven (www.personalisednutritionandhealth.com). Ook is er steeds meer bekend over de psychologie achter voedingskeuzes en motivaties en wordt geëxperimenteerd met het inzetten van nudging om mensen gemakkelijker gezonde voedingskeuzes te laten maken. Ook is er steeds meer aandacht voor voedselonderwijs, van het basisonderwijs tot aan geneeskunde.

\section{Veerkrachtig}

Diversiteit van soorten bedrijven, producten en betrokken actoren maken een voedselsysteem robuuster en brengen vernieuwing. Het op peil houden van gezonde populaties van zeldzame gewassen, vee, en andere productiedieren is belangrijk voor de genen- biodiversiteit en ondersteunt de zoektocht naar duurzamere en gezondere producten. Daarnaast maken sommige zeldzame soorten onderdeel uit van het Nederlands cultureel erfgoed. Mensen met verschillende achtergronden, zowel binnen als buiten de landbouw, vinden het waardevol deze soorten in stand te houden. Dit gedeelde waardebesef verbindt een diversiteit van actoren en creëert openingen voor nieuwe spelers. Ook bij personen die in het grootstedelijke gebied wonen groeit de aandacht voor het voedselsysteem en stedelingen experimenteren met stadslandbouw, vertical farming, moestuinprojecten en nieuwe gezondere takeaway-/fastfoodopties. Daarnaast zien wij een wildgroei aan voedselfestivals, boerenmarkten en voedselbloggers/-vloggers die een nieuwe impuls geven aan het voedselsysteem en kunnen bijdragen aan kortere ketens en aanpassingen in voedselvoorkeuren. Andere vormen van sociale innovatie zijn organisaties die voedselproductie en verwerking gebruiken als therapie, educatie of dagbesteding. Verder is een diversiteit aan bedrijfstypes en bedrijfsmodellen in het voedingssysteem van belang om crisissituaties op te opvangen en vernieuwing te brengen.

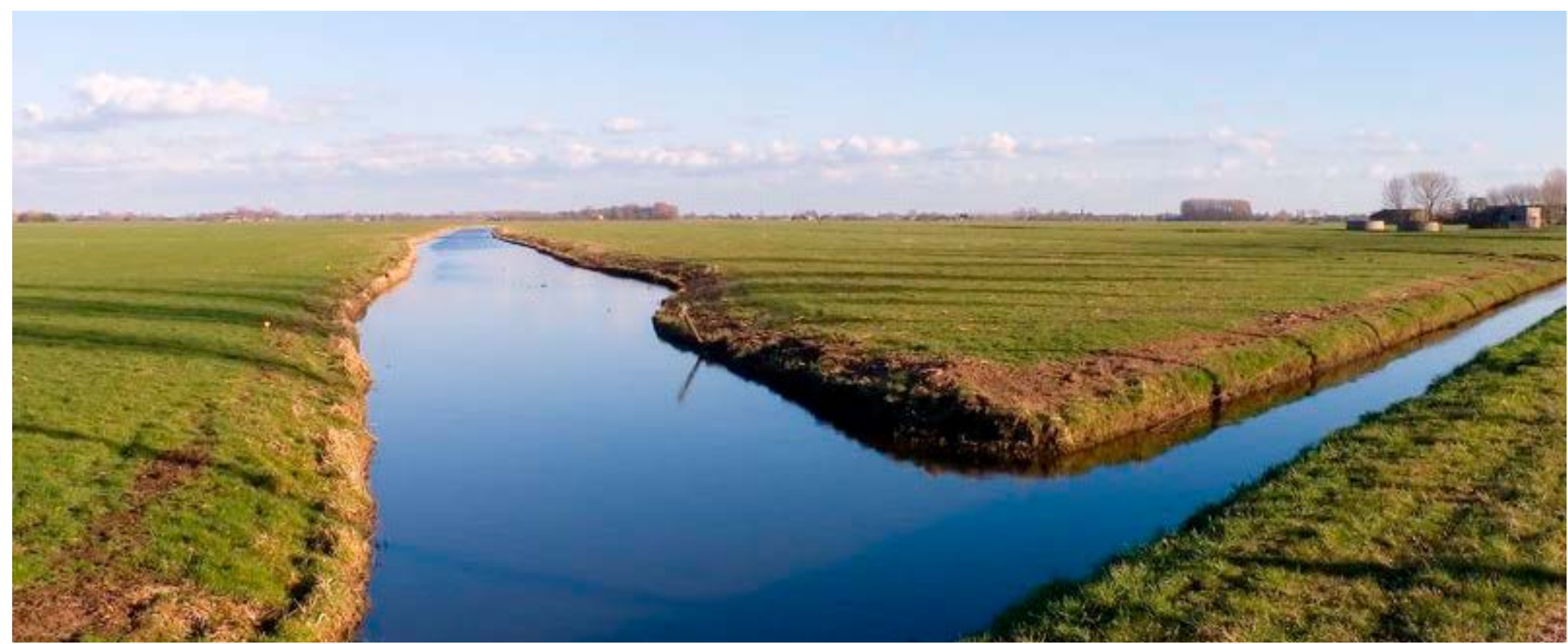

(1) Een duurzamer en gezonder voedselsysteem

(2) Opgaven voor een duurzamer en gezonder voedselsysteem

3 Vijf richtingen voor voedselsysteeminnovatie

Duurzame Productie Plantaardige en nieuwe eiwitten

Circulaire economie Gezonde consumptie Veerkrachtig

(4) Systeeminnovatiebarrières

(5) Voedselsysteeminnovaties kansen in Nederland

(6) Referenties 


\section{Systeeminnovatiebarrières}

\section{Complex samenspel van veel dimensies}

Een systeeminnovatie is een vernieuwing die de grenzen van organisaties overstijgt en maatschappelijke, technologische, economische, ecologische, en institutionele regels en praktijken verandert. Systeeminnovaties zijn nodig om complexe duurzaamheids- en gezondheidsproblemen op te lossen. Echter, systeeminnovaties zijn moeilijk te sturen, juist omdat het de grenzen van organisaties overstijgt. Het gaat om structurele veranderingen op het gebied van techniek, gedrag, relaties, regelgeving en institutionele omgeving en vraagt om inspanningen bij zowel bedrijven, burgers, beleid, maatschappelijke organisaties en onderzoekers.

\section{Markt-, systeem- en transformatiefalen remmen verandering}

Figuur 1 visualiseert het voedselsysteem (zie pagina 3) en illustreert dat voedselproductie vooral een economische aangelegenheid is. Verandering in voedselproductie is voornamelijk een ondernemersvraagstuk en markt aangelegenheid. Echter vanwege falende marktwerking, onder andere omdat milieu- en volksgezondheidkosten niet worden meegenomen in het bedrijfsmodel (Jong, 2018) en omdat nieuwe, innovatieve bedrijven moeilijk markttoegang krijgen in het voedseldomein (Overbeek et al., 2017; Hoes et al., 2016), is interveniëren wenselijk. Frenken en Hekkert (2017) beargumenteren dat naast marktfalen, ook systeem- en transformatiefalen een overgang naar een duurzamere wereld in de weg staan (zie ook Weber en Rohracher (2012). Systeemfalen gaat onder andere over verouderde regelgeving, conservatieve maatschappelijke normen en gebrekkige netwerken, kennis en competenties. Transformatiefalen betreft het gebrek aan urgentie, reflexiviteit, leervermogen, visie, vraagarticulatie en beleidscoördinatie (Frenken en Hekkert, 2017).
(1) Een duurzamer en gezonde voedselsysteem

(2) Opgaven voor een duurzamer en gezonder voedselsysteem

(3) Vijf richtingen voor voedselsysteeminnovatie

(4) Systeeminnovatiebarrières

Complex samenspel van veel dimensies

Markt-, systeem- en transformatiefalen remmen verandering

Relatie niche en regime

Systeeminnovatie en weerstand

Gedrag is moeilijk te doorgronden

(5) Voedselsysteeminnovaties kansen in Nederland

(6) Referenties 


\section{Relatie niche en regime}

Ondanks markt-, systeem- en transformatiefalen kunnen er historische systeeminnovaties aangewezen worden. Een model dat systeeminnovatieprocessen duidt, en is ontwikkeld op basis van de analyse van historische systeeminnovaties, is het multi-level perspectief. Het multi-level perspectief maakt onderscheid tussen niches (microniveau), regime (mesoniveau) en landschap (macroniveau) (Geels, 2002).

Niches zijn omgevingen waar actoren kunnen experimenteren met innovaties die afwijken van het gangbare. Het regime staat voor de gevestigde praktijk, cultuur, normen en instituties. Het landschap gaat over de grote internationale veranderingen onder andere op maatschappelijk, ecologisch, economisch en politiek vlak die zowel de niches als het regime beïnvloeden. Om systeemverandering te realiseren is het van belang dat innovaties (vanuit de niche) een positie verwerven in het regime. Geels en Schot (2007) beschrijven dat de relatie tussen innovaties in de niche en het bestaande regime van sterk competitief tot zelfs symbiotisch kan zijn.

\section{Systeeminnovatie en weerstand}

Omdat het regime bestaat uit diverse actoren en instituties zullen innovaties in de praktijk, afhankelijk van de actor, zowel omarmd als bejubeld worden door verschillende subgroepen en actoren in het regime en de niche (Hoes en Regeer, 2015). Belanghebbenden kunnen uiteenlopende normatieve perspectieven hebben ten opzichte van innovaties. Het in kaart brengen van deze visies van belanghebbenden is nodig. Zo kunnen eventuele ongewenste effecten vooraf gesignaleerd worden, en waar mogelijk, oplossingen geïntegreerd worden in het ontwerp. Echter, grootschalige innovaties brengen bijna altijd ook onverwachte effecten met zich mee. En innovaties zullen zelden geheel en door iedereen geaccepteerd worden. Sommige belanghebbenden verwachten immers dat de innovatie schade kan berokkenen aan bijvoorbeeld hun lokale omgeving (zoals windmo-

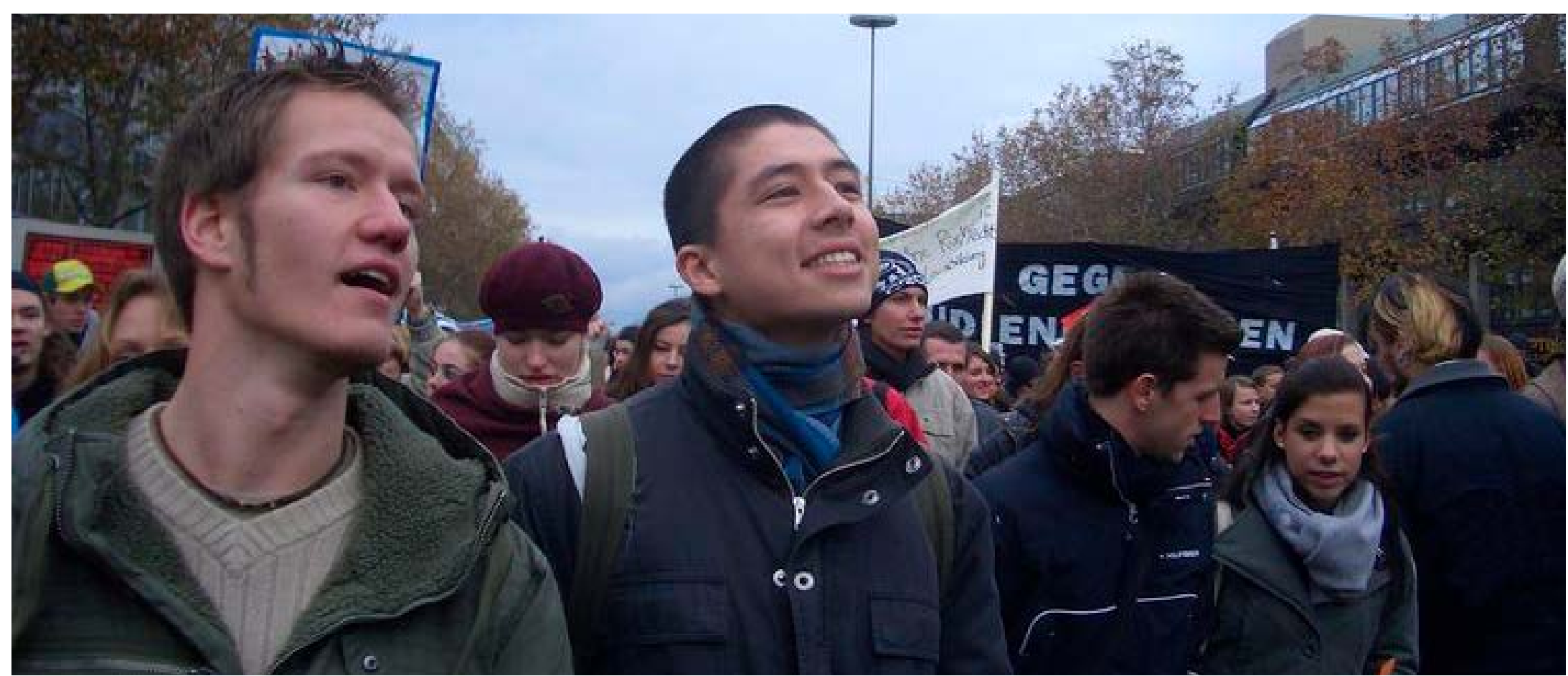




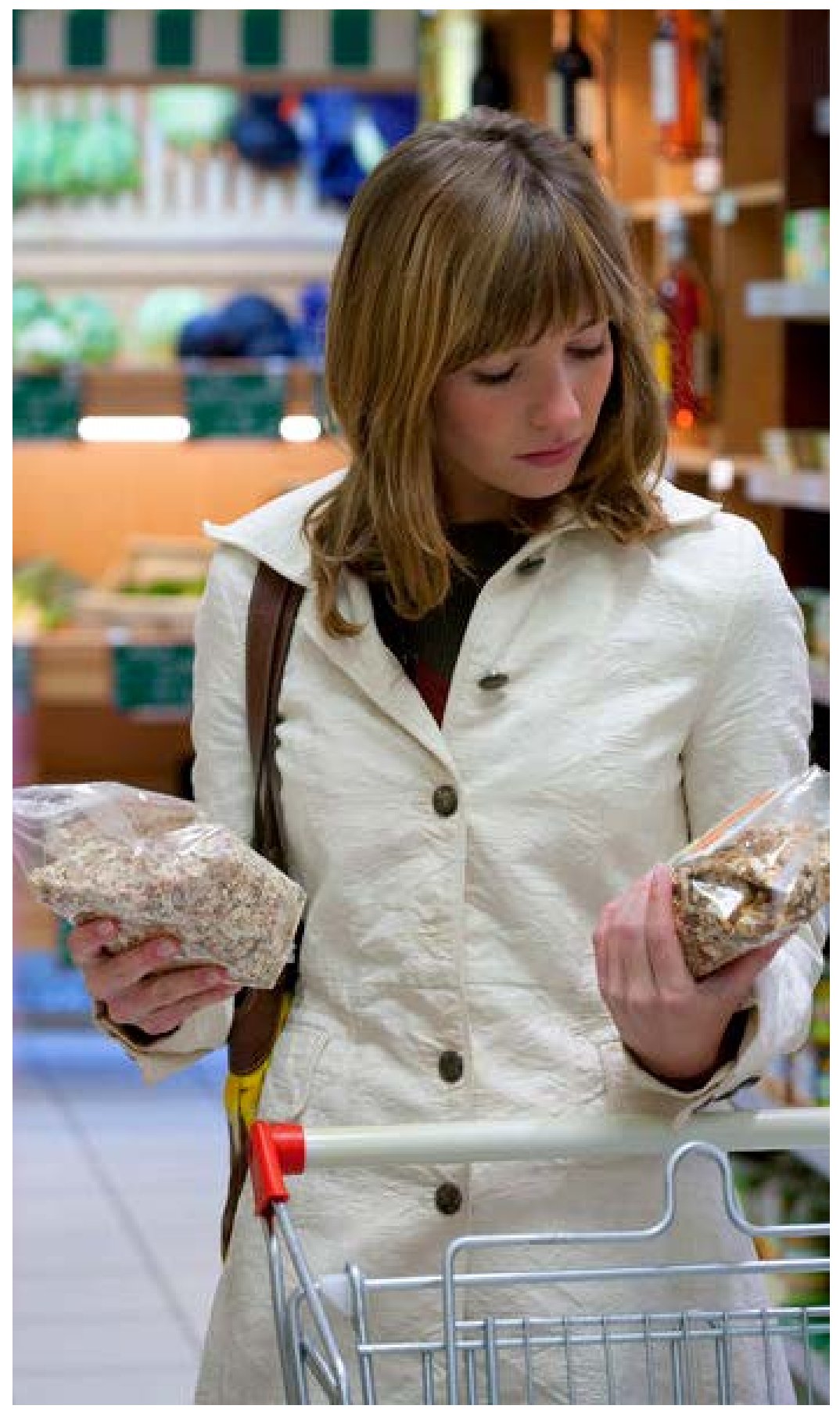

lens) of hun concurrentiepositie (grote bedrijven). Kortom, het is onvermijdelijk dat innovaties onzekerheid met zich meebrengen en dat sommige actoren verwachten te profiteren van innovaties terwijl anderen er zich de dupe van voelen. In dit opzicht kan worden verwacht dat systeeminnovatieve projecten vaak op verzet stuiten en dat het omgaan met weerstand een onderdeel vormt van systeeminnovatieprocessen (Hoes, 2011).

\section{Gedrag is moeilijk te doorgronden}

Daarnaast omvatten voedselsysteeminnovaties brede verspreiding van ontwikkelde innovaties, bij zowel boeren, andere organisaties en consumenten. Voor boeren en andere organisaties omvat dit het aanpassen van hun bedrijfsvoering en in sommige gevallen zelfs het beëindigen van hun huidige bedrijfsmodel en overstappen naar een nieuw bedrijfsmodel. Dit vraagt grote investeringen, zowel persoonlijk als financieel, waarbij de uiteindelijke baten vaak onduidelijk of onzeker zijn.

Voor consumenten gaat het om aanpassingen in het eetpatroon en in de keuze van voedselproducten. Gedragsverandering bij consumenten realiseren is weerbarstig en alleen informatievoorziening over de herkomst, duurzaamheids- en gezondheidsimpact van producten is onvoldoende. Gedrag hangt ook af van onder andere de context, het product en de doelgroep. Binnen het consumentenonderzoek is er een duidelijk beeld van welke factoren van belang zijn bij gezonde en duurzame consumptie. Het is echter nog onduidelijk hoe deze factoren zich tot elkaar verhouden. Daarom is het nog lastig om interventies te ontwikkelen die effecten op de lange termijn hebben als het gaat om gedragsverandering bij consumenten (Garnett et al., 2015). Een integrale aanpak gekoppeld aan een gedragen gedragsmodel en een gestructureerde consumentendataverzameling zijn nodig om dit te achterhalen (Onwezen et al., 2017).

Met de bovenstaande transitiebarrières kan de moed in de schoenen zakken om überhaupt nog te investeren in voedseltransities. Gelukkig zijn er ook ontwikkelingen in de praktijk die hoop en energie geven. Deze krijgen hieronder aandacht.

(1) Een duurzamer en gezonder voedselsysteem

(2) Opgaven voor een duurzamer en gezonder voedselsysteem

(3) Vijf richtingen voor voedselsysteeminnovatie

(4) Systeeminnovatiebarrières

Complex samenspel van veel dimensies Markt-, systeem- en transformatiefalen remmen verandering

Relatie niche en regime

Systeeminnovatie en weerstand

Gedrag is moeilijk te doorgronden

(5) Voedselsysteeminnovaties kansen in Nederland

(6) Referenties 


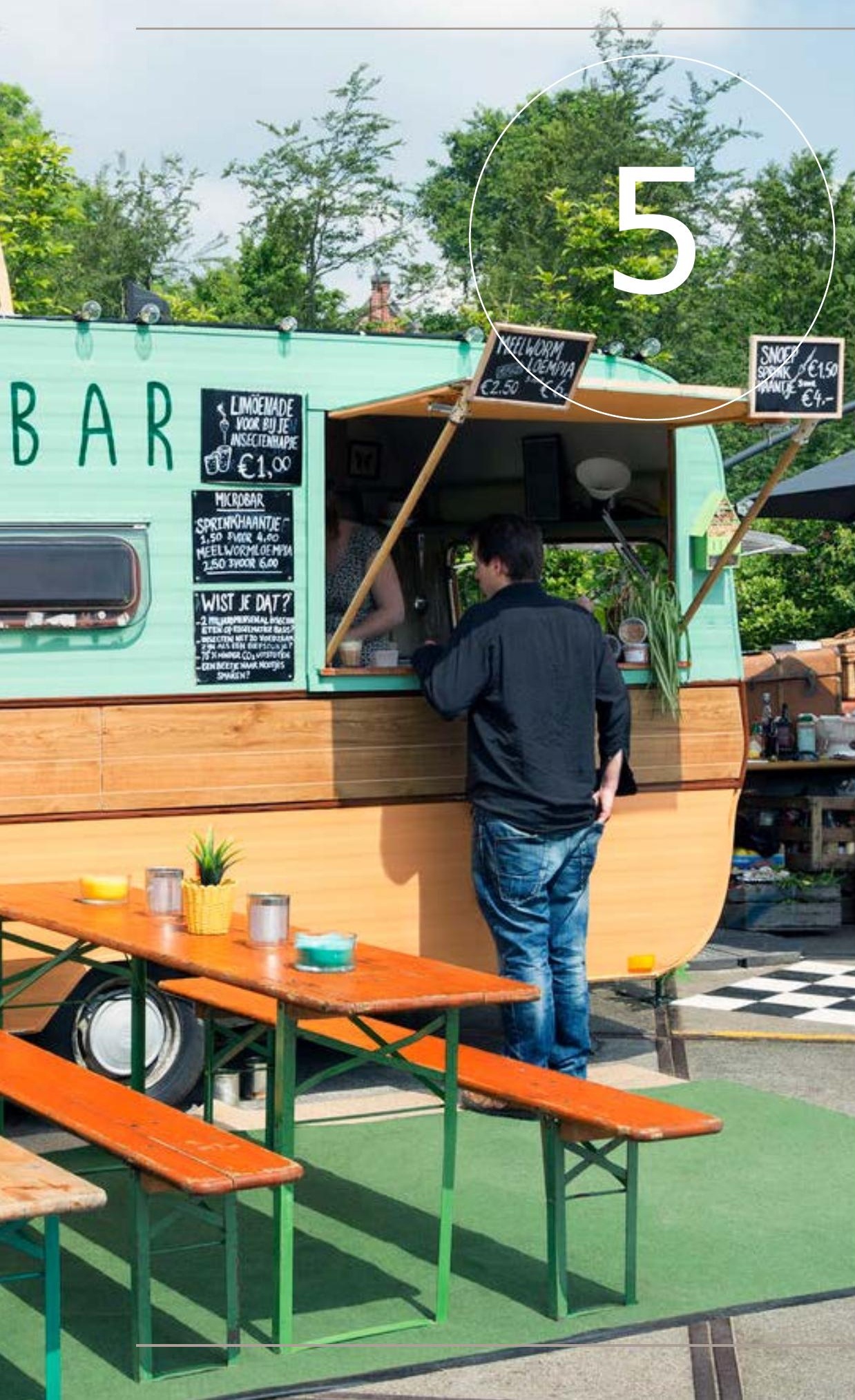

\section{Voedselsysteeminnovaties kansen in Nederland}

In Nederland is een diversiteit aan nieuwe voedselinitiatieven die zich bijvoorbeeld richten op duurzamere productie, alternatieve producten, korte ketens, stadslandbouw en voedselverspilling. Deze initiatieven worden geïnitieerd en ondersteund door zowel ondernemers (start-ups en scale-ups), bedrijfsleven, onderzoek, overheid en burgers.

Innovatieve ondernemers die gaan voor duurzaamheid en gezondheid

Een greep van Nederlandse start-ups en scale-ups die werken aan gezondheid en duurzaamheid in het voedingsdomein zijn Buitengewone Varkens, Dutch Weedburger, Good Bite, Herenboeren, Kromkommer, Lgem, Livar, MacuView, Mosa Meat (kweekvlees), Rondeel eieren, Rotterzwam, TastyBugs, Urban Farmers, De Vegetarische Slager, Wildernis Vlees, Zeewaar (Hoes et al., 2016). Hoewel veel van deze initiatieven worstelen met de levensvatbaarheid (Overbeek et al., 2017), wordt er ook veel geleerd over het succesvol opstarten en door ontwikkelen van (sociale) ondernemingen (zoals Koppert Cress). Het besef groeit dat het verstandig is met kleine investeringen te beginnen waarbij een vroege, uitgeklede versie van de innovatie wordt geconcretiseerd. De potentiële waarde van de innovatie kan dan in een vroege fase worden getest en feedback van gebruikers kan in een vroege fase van het ontwerpproces worden meegenomen (ofwel een minimum viable product, MVP). Deze gedachtegang past bij een agile ontwikkelproces waarbij de ambities hoog zijn maar de concrete vervolgacties behapbaar (www.scrumcompany.nl) (Boer, 2015).

\section{Gevestigde bedrijven die investeren in verduurzaming}

Ook grotere, gevestigde bedrijven investeren in verduurzaming en gezondheid om zo proactief zorgen vanuit de maatschappij op te
(1) Een duurzamer en gezonder voedselsysteem

(2) Opgaven voor een duurzamer en gezonder voedselsysteem

(3) Vijf richtingen voor voedselsysteeminnovatie

(4) Systeeminnovatiebarrières

5 Voedselsysteeminnovaties kansen in Nederland

Innovatieve ondernemers die gaan voor duurzaamheid en gezondheid

Gevestigde bedrijven die investeren in verduurzaming

De overheid als aanjager, ondersteuner en handhaver

De burger en andere als kritische klant, initiatiefnemer en activist

Naar een duurzamer en gezonder voedselsysteem in Nederland

(6) Referenties 
pakken en hun licence to produce te behouden (zie bijlage 1). Dit doen zij vooral door inzicht te krijgen in de effecten van hun bedrijfsvoering op de planeet, mensen en dieren en ketenafspraken te maken over minimumeisen en verbeterde bedrijfsvoering (zie bijvoorbeeld duurzamezuivelketen.nl, globalgap.nl en www.sustainabilityconsortium.org). Daarnaast ondersteunen zij ondernemers via co-creatie en innovatie (bijvoorbeeld ecosysteme.danone.com). Ook gevestigde partijen buiten het voedseldomein zorgen voor een innovatie-impuls zoals ICT-bedrijven die oplossingen bieden voor ketenpartners en zelf experimenteren en investeren in het voedseldomein.

\section{De overheid als aanjager, ondersteuner en handhaver}

Ook vanuit de overheid is de afgelopen decennia geëxperimenteerd met het aanjagen van duurzame innovaties in het voedingsdomein. Zo werden reguliere onderzoeksmiddelen ingezet en specifieke programma's zoals het BSIK-programma TransForum (van 20052010), InnovatieNetwerk (2000-2015), DuurzaamDoor en publiek- private samenwerkingen in specifieke sectoren zoals Courage (melkveehouderij) en SIGN (glastuinbouw). In het recente verleden werden dergelijke innovatieve programma's buiten het gangbare overheidsbeleid geplaatst. Echter, het overheidsapparaat en de rijksoverheid zijn aan het veranderen en er ontstaat hier meer ruimte om vanuit een participerende en/of netwerkende rol duurzaamheidsinitiatieven te ondersteunen zonder de rol van handhaver en ordebewaker te verliezen (Hoes et al., 2018; Steen et al., 2014). De rol van handhaver en ordebewaker betekent ook het aanpakken van onduurzame en ongezonde praktijken bij bedrijfsleven en burgers. Daarnaast wordt gekeken hoe aanpalend beleid, zoals het Gemeenschappelijk landbouwbeleid (GLB), ingezet kan worden om een duurzamer en gezonder voedselsysteem te realiseren.

Daarnaast spelen regionale overheden een belangrijke rol in het aanjagen en ondersteunen van voedselinnovaties die bijdrage aan duurzaamheid en gezondheid. City deal plaatsen voedsel op de stedelijke agenda in Almere, Amsterdam, Den Bosch, Den Haag, Ede, Groningen, Helmond, Leeuwarden, Oss, Rotterdam, Utrecht en Venlo.
(1) Een duurzamer en gezonder voedselsysteem

(2) Opgaven voor een duurzamer en gezonder voedselsysteem

(3) Vijf richtingen voor voedselsysteeminnovatie

(4) Systeeminnovatiebarrières

5 Voedselsysteeminnovaties kansen in Nederland

Innovatieve ondernemers die gaan voor duurzaamheid en gezondheid

Gevestigde bedrijven die investeren in verduurzaming

De overheid als aanjager, ondersteuner en handhaver

De burger en andere als kritische klant, initiatiefnemer en activist

Naar een duurzamer en gezonder voedselsysteem in Nederland 
De burger en andere als kritische klant, initiatiefnemer en activist

Daarnaast maken steeds meer burgers zich zorgen over het huidige voedselsysteem en zijn ze zich bewust van de milieu en gezondheidsimpact van hun voedselkeuzes. Bij sommige burgers leidt dit tot aanpassingen in hun aankoop- en consumptiegedrag. Andere ontwikkelen zelf een alternatief of sluiten aan bij een groep. Denk hierbij aan collectieve moestuinen, het organiseren van voedselfestivals en het maken van voedselblogs of vlogs. Ook zijn er burgers die actief het beleid proberen te beïnvloeden, zoals burgerinitiatieven en lokale protest bewegingen (Hajer, 2011). Ook andere actoren en partijen zoals koks (Dutch Cuisine), zorgverzekeraars en scholen lobbyen of doorbreken bestaande routines.

\section{Naar een duurzamer en gezonder voedselsysteem in Nederland}

Deze publicatie biedt een beknopte samenvatting van de huidige Nederlandse opgaven voor een duurzamer en gezonder voedselsysteem en somt de lopende voedselinnovaties op die een bijdrage kunnen leveren aan een duurzamer en gezonder voedselsysteem. Ook schetst het dat de verwachtingen met betrekking tot het simpelweg 'realiseren van' systeeminnovaties niet te hooggespannen moeten zijn. Systeeminnovaties zijn moeilijk te sturen en brengen ook teleurstelling en tegenwind met zich mee en vragen vaak om pijnlijke keuzes. Gelukkig zijn er ook veel inspanningen en energie bij diverse actoren, van ondernemers, gevestigde bedrijven, overheid, onderzoekers en burgers, om te komen tot een beter voedselsysteem. Europese en internationale ontwikkelingen, zoals de SDG's, versterken dit. Wanneer de redenering van Gartners Hype Cycle wordt gevolgd, is het aannemelijk dat Nederland voorbij de verwachting is dat een duurzamer en gezonder voedselsysteem snel te realiseren is. En worden er nu reëlere stappen gezet naar een duurzamere wereld (Gartner, Hype Cycle). De kunst is om de Nederlandse initiatieven te verbinden aan kansrijke voedselsysteeminnovatierichtingen die energie geven zonder naïef te zijn over de investeringen en pijnlijke keuzes die dit vergt. Dit vraagt om een langetermijnaanpak bij zowel overheid als bedrijfsleven waarbij het toekomstperspectief richtinggevend is, er duidelijkheid komt over welke praktijken in 2050 nog maatschappelijk acceptabel zijn en er juist ingezet wordt op het ondersteunen van praktische innovatieve initiatieven die een bijdrage kunnen leveren aan het realiseren van het toekomstbeeld.

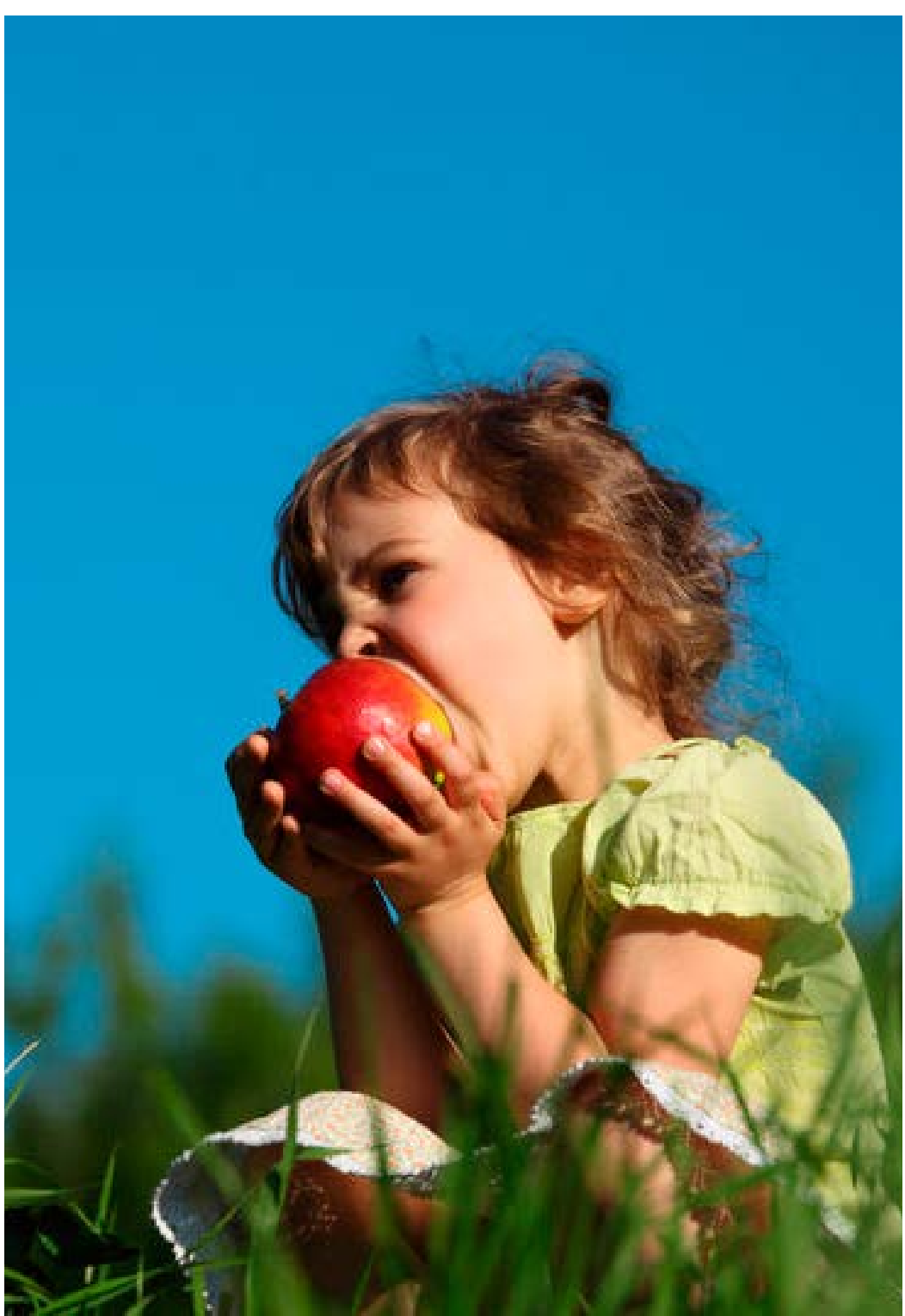

(1) Een duurzamer en gezonder voedselsysteem

(2) Opgaven voor een duurzamer en gezonder voedselsysteem

(3) Vijf richtingen voor voedselsysteeminnovatie

(4) Systeeminnovatiebarrières

Voedselsysteeminnovaties kansen in Nederland

Innovatieve ondernemers die gaan voor duurzaamheid en gezondheid

Gevestigde bedrijven die investeren in verduurzaming

De overheid als aanjager, ondersteuner en handhaver

De burger en andere als kritische klant, initiatiefnemer en activist

Naar een duurzamer en gezonder voedselsysteem in Nederland

(6) Referenties 
Bakker, E. de en H. Dagevos (2010) Vleesminnaars, vleesminderaars en vleesmijders. Duurzame eiwitconsumptie in een carnivore eetcultuur. edepot.wur nl/141595 LEI rapport 2010-003, Den Haag: lei Wageningen ur, 207 pagina's.

Berkum, S. van, J. Dengerink en R. Ruben (2018) The food systems approach: sustainable solutions for a sufficient supply of healthy food. library.wur.nl/WebQuery/ wurpubs/fulltext/451505 Wageningen University \& Research, Wageningen Economic Research, Memorandum 2018-064, 32 pagina's.

Berkhout, P., S. van Berkum en R. Ruben (2018) Van koopman tot kopman. Naar een nieuwe internationale positionering van de Nederlandse agrosector. edepot.wur.nl/447419 Wageningen University \& Research, 67 pagina's.

Boer, de P., M. Bruggink, M. Bruns, N. van de Hoef, G. Peters, M. Roozemond en W. Wijnands (2015) Scrum in actie, maak van elk project een succes. ISBN 9789047008378, 192 pagina's.

Brabantse Zorgvuldigheidsscore Veehouderij (2015-2018) bzv.brabant.nl/public/ (Brabantse Zorgvuldigheidsscore Veehouderij).

Dagevos, H. (2017) Duurzame voedselpolitiek: van generiek naar energiek. In: Rood-groene politiek voor de 21e eeuw / de Coninck, H., Hurenkamp, M., Melsen, L., Opschoor, H., Van Gennep - ISBN 9789461644534 - pagina's 211 - 228.

Dekker, S.E.M. (2012) Exploring ecological sustainability in the production chain of organic eggs. Proefschrift WUR, ISBN 9789461731494 - 175 pagina's.

Dam, M. van (2017, 4 juli) Voortgang invulling zesde actieprogramma Nitraatrichtlijn [Kamerbrief]. Geraadpleegd van kamerbrief-over-voortgang-invulling-zesde-actieprogramma-nitraatrichtlijn.pd

Food System Map, 2014, www.nourishlife.org/teach/food-system-tools/

Fraters, B, A.E.J. Hooijboer, A. Vrijhoef, J. Claessens, M.C. Kotte, G.B.J. Rijs, A.I.M. Denneman, C. van Bruggen, C.H.G. Daatselaar, H.A.L. Begemanen J.N. Bosma (2016), Landbouwpraktijk en waterkwaliteit in Nederland; toestand (2012-2014) en trend (1992-2014). Resultaten van de monitoring voor de Nitraatrichtlijn. www.rivm. nl/bibliotheek/rapporten/2016-0076.pdf RIVM Rapport 2016-0076.

Frenken, K. en M. Hekkert (2017) Innovatiebeleid in tijden van maatschappelijke uitdagingen. https://dspace.library.uu.nl/handle/1874/362497 Verschenen in het essaybundel "Sturen in een verweven dynamiek, Perspectieven op complexiteit en oriëntaties voor beleid" Ministerie van Economische zaken, 46 - 57 pagina's.
Fresco, L. O. en K.J. Poppe (2016) Towards a Common Agricultural and Food Policy. dx.doi.org/10.18174/390280 Wageningen Economic Research, 58 pagina's.

Garnett, T., S. Mathewson, P. Angelides en F. Borthwick (2015) Policies and actions to shift eating patterns: What works? - A review of the evidence of the effectiveness of interventions aimed at shifting diets in more sustainable and healthy directions. www.fcrn.org.uk/sites/default/files/fcrn_chatham_house_0.pdf Oxford: Food Climate Research Network / Chatham House.

Gartner, Hype-cycle, www.gartner.com/technology/research/methodologies/ hype-cycle.jsp

Geels, F.W. (2002) Technological transitions as evolutionary reconfiguration processes: A multi-level perspective and a case-study, Research Policy, 31(8-9), pp. $1257-1274$.

Geels, F.W. en J. Schot (2007) Typology of sociotechnical transition pathways, Research Policy, 36(3), 399-417.

Haalboom, F. (2017) Negotiating zoonoses: Dealings with infectious diseases shared by humans and livestock in the Netherlands (1898-2001). Proefschrift Universiteit Utrecht. 267 pagina's.

Hajer, M. (2011) De energieke samenleving. Op zoek naar een sturingsfilosofie voor een schone economie www.pbl.nl/sites/default/files/cms/publicaties/ Signalenrapport_web.pdf Rapport PBL Planbureau voor de Leefomgeving, PBLpublicatienummer: 500246001, 76 pagina's.

Hekkert, M.P., R.A.A. Suurs, S.O. Negro, S. Kuhlman en R.E.H.M. Smits (2007) Functions of innovation systems: A new approach for analysing technological change. Technological Forecasting and Social Change 74, 413-432.

HLPE, the High Level Panel of Experts (2017) Nutrition and food systems. A report by the High Level of Experts on Food Security and Nutrition of the Committee on World Food Security. www.fao.org/3/a-i7846e.pdf Rome, 151 pagina's.

Hoes, A-C., H. Dagevos en G. Overbeek (2018) Naar een sociaal-innovatieve overheid. Platform $\mathrm{O}$, artikel gepubliceerd op 22 februari 2018, platformoverheid.nl. platformoverheid.nl/naar-een-sociaal-innovatieve-overheid/

Hoes, A-C., C. Savelkouls, C. Zondervan en V. Beekman (2016) Voedselinnovaties in Nederland, Een greep uit vernieuwende initiatieven. edepot.wur.nl/393941 WUR publicatie 2016-108.
(2) Opgaven voor een duurzamer en gezonde voedselsysteem

(3) Vijf richtingen voo voedselsysteem innovatie

4) Systeeminnovatie barrières

(5) Voedselsysteeminnovaties kansen in Nederland

Referenties 
Hoes, A.-C., B.J. Regeer (2015) Adoption of novelties in a pluralist society: exploring an agropark case study, Journal of Environmental Policy \& Planning. 17, 3-24.

Hoes, A.-C. (2011) Inside the black box of agricultural innovation projects, exploring the interactions between farmers, greenhouses, scientists, pigs \& neighbours,

Proefschrift VU Amsterdam, Oisterwijk, Nederland; Boxpress. Available at dare.ubvu. vu.nl/handle/1871/32365

Hoste, R., (2017) International comparison of pig production costs 2015; Results of InterPIG. www.wur.nl/upload_mm/7/2/1/6b41db84-9af8-467c-845b-

55cf1308635f_2017-048\%20Hoste_def.pdf Wageningen, Wageningen Economic Research, Report 2017-048.

Jong, J. de (2018) Voor een wijziging van het systeem is er meer nodig dan een oproep tot een Landbouwakkoord. www.foodlog.nl/artikel/voor-een-wijziging-vanhet-systeem-is-er-meer-nodig-dan-een-oproep-tot-een/ Foodlog, 4 juli 2018.

Kampers, F.W.H. en L. O. Fresco in collaboration with colleagues from Wageningen University \& Research (2017) Food Transitions 2030. www.wur.nl/upload_mm/a/6/0/ c2f49059-642e-4699-8be5-286ebb776557_FoodTransitions2030-A5-LR.pdf Wageningen University \& Research, 63 pagina's.

Kemmers, R.H. (2011) Effecten van verzuring op bodemleven en stikstofstromen in bossen. edepot.wur.nl/175621 Alterra-rapport 2204, ISSN 1566-7197.

Landelijke Meetnet Mestbeleid (2017) Jubileumeditie LMM-nieuws, 25 jaar Landelijk Meetnet effecten Mestbeleid. https://www.wur.nl/upload_mm/a/2/a/cca3920f-959d4928-8311-00ac2eb7deed_247e087d-2cb2-4c8e-9fe3-12f9cf8d6ac1_LMMnieuws\%20juni\%202017\%20-\%2025\%20jaar.pdf, jaargang 10, nr 1, 31 pagina's.

LNV (2010) Nieuwsbrief Kennis en Innovatie. Thema Biodiversiteit. Nummer 7, september 2010.

Maassen C.B.M., E. van Duijkeren, Y.T.H.P. van Duynhoven, A. Dusseldorp, P. Geenen, A.A. de Koeijer, M.P.G. Koopmans, F. Loos, W.F. Jacobs-Reitsma, R. de Jonge en A.W. van de Giessen (2012) Infectierisico's van de veehouderij voor omwonenden. www.rivm.nl/dsresource?objectid=3dfe2794-adfc-4ae1-90dd-d48ab4 72070f\&type $=$ org\&disposition $=$ inline RIVM, 66 pagina's.

Maassen K, L. Smit, I. Wouters, E. van Duijkeren, I. Janse, T. Hagenaars, J. IJzermans, W. van der Hoek en D. Heederik (2016) Veehouderij en gezondheid omwonenden. www.rivm.nl/bibliotheek/rapporten/2016-0058.html RIVM Rapport 2016-0058. 136 pagina's.
Muilwijk, H., H. Westhoek en M. de Krom (2018) Voedsel in Nederland: Verduurzaming bewerkstellingen in een vee/vormig systeem. www.pbl.nl/sites/ default/files/cms/publicaties/pbl-2018-notitie-voedsel-in-nederland-3239.pdf Rapport PBL Planbureau voor de Leefomgeving, PBL-publicatienummer: 3239 30 pagina's.

NVWA, De Nederlandse Voedsel- en Warenautoriteit (2013) Residuen van gewasbeschermingsmiddelen op groente en fruit. Overzicht van uitkomsten NVWAinspecties juli 2011 - juni 2013. http://edepot.wur.nl/295202 10 pagina's.

Ocke M.C., I.B. Toxopeus, M. Geurts, M.J.B. Mengelers, E.H.M. Temme en N. Hoeymans (2017) Wat ligt er op ons bord? Veilig, gezond en duurzaam eten in Nederland. www.rivm.nl/dsresource?objectid=187a9d57-2ef2-4340-985a402b146702c4\&type=PDF RIVM Rapport 2016-0200, 94 pagina's.

Onwezen, M., M. Reinders en H. Snoek (2016) De Agrifoodmonitor 2016; Hoe burgers de Agri \& Food sector waarderen. edepot.wur.nl/398441 Wageningen, Wageningen Economic Research, Rapport. 2016-111. 48 pagina's.

Onwezen, M., E. Bouwman en R. Hovens (2017) Kennishiaten duurzaam en gezond Consumeren. Bijdrage aan Strategisch Kennis en Innovatie Programma Voedsel http://edepot.wur.nl/428683 Wageningen, Wageningen Economic Research, NOTA 2017-123a, 22 pagina's.

Os, J. van, M.H. Bokma-Bakker, W. Kuindersma, T. Selnes en T.J.A. Gies, (2013) Nieuwe wegen naar ontwikkelingsgericht werken; Handelingsperspectieven voor de overheid rond duurzame ontwikkeling en maatschappelijke acceptatie van veehouderij. edepot.wur.nl/275388 Wageningen, Alterra Wageningen UR (University Research centre), Alterra-rapport 2450, 84 pagina's.

Overbeek, G, H. Dagevos en A-C. Hoes (2017) Zaadje op de rotsbodem: nieuwe voedselinitiatieven vinden niet snel een voedingsbodem. edepot.wur.nl/413316 Vork 4, 1. - ISSN 2352-2925 58-63 pagina's.

Peters, P. (2013) Ontmasker de voedings- en supplementengoeroe, www.foodlog.nl/ artikel/ontmasker-de-voedings-en-supplementengoeroe Foodlog, 20 september 2013.

Reijs, J. (2018) Duurzame productiesystemen als kans voor Nederland. Blog Agrodebat Wageningen Economic Research, 2018, 12 januari. weblog.wur.nl/ agrodebat/duurzame-productiesystemen-kans-voor-nederland/

RLI, Raad voor de leefomgeving en infrastructuur (2018) Duurzaam en Gezond: Samen naar een houdbaar voedselsysteem. www.rli.nl/sites/default/files/duurzaam_ en_gezond_samen_naar_een_houdbaar_voedselsysteem_def_1.pdf Publicatie Rli 2018/02, ISBN 978-90-77166-73-4, 98 pagina's.
(1) Een duurzamer en gezonder voedselsysteem

(2) Opgaven voor een duurzamer en gezonder voedselsysteem

(3) Vijf richtingen voo voedselsysteem innovatie

(4) Systeeminnovatiebarrières

(5) Voedselsysteeminnovaties kansen in Nederland

Referenties 
Rijksoverheid (2018) Antibioticaresistentie in de veehouderij www.rijksoverheid.nl/ onderwerpen/antibioticaresistentie/antibioticaresistentie-in-de-veehouderij

Rijks Instituut voor de Volksgezondheid en Milieu, Percentage metabool syndroom naar leeftijd en geslacht. https://www.rivm.nl/Documenten_en_publicaties/

Wetenschappelijk/Tabellen_grafieken/Preventie_Ziekte_Zorg/NL_de_Maat/Metabool syndroom_naar_leeftijd_en_geslacht (versie 2012).

RVO (2016) De Nederlandse landbouw en het klimaat. www.rvo.nl/sites/default/ files/2016/12/RVO_De\%20Nederlandse\%20landbouw\%20en\%20het $\% 20$ klimaat Broch_def.pdf Publicatienummer: RVO-075-1601/BR-DUZA, 27 pagina's.

Snoo, G.R. en M.G. Vijver (2012) Bestrijdingsmiddelen en waterkwaliteit. http:// www.bestrijdingsmiddelenatlas.nl/media/1114/Bestrijdingsmiddelen_en_waterkwaliteit.pdf Rapport Universiteit Leiden, Centrum voor Milieuwetenschappen, 176 pagina's.

Steen, M. van der, J. Scherpenisse, M. Hajer, O-J. van Gerwen en S. Kruitwagen (2014). Leren door doen: Overheidsparticipatie in een energieke samenleving. http://www.pbl.nl/sites/default/files/cms/publicaties/PBL-2014-Leren-door-doen.pdf ISBN: 978-90-75297-40-9, Den Haag: Nederlandse School voor Openbaar Bestuur en Planbureau voor de Leefomgeving, 69 pagina's.

Termeer, K., H. Dagevos, G.E. Breeman en A-C. Hoes (2013) Maatschappelijk vertrouwen in de varkenshouderij. library.wur.nl/WebQuery/wurpubs/fulltext/279565 Den Haag: LEI, onderdeel van Wageningen UR, 98 pagina's.

Greep uit duurzaamheidsinitiatieven vanuit voedsel multinationals

www.ecosysteme.danone.com

www.duurzamezuivelketen.nl

www.mars.com/global/sustainable-in-a-generation

https://www.nestle.com/csv/impact

www.sustainabilityconsortium.org

www.trouw.nl/groen/jumbo-wil-duurzame-zuivel-maar-steggelt-overhogere-vergoeding-aan-melkboeren aea877ad/
Vink, M. en D. Boezeman (2018) Naar een wenkend perspectief voor de Nederlandse landbouw. Voorwaarden voor verandering. www.pbl.nl/sites/default/files/cms/ publicaties/pbl-2018-naar-een-wenkend-perspectief-voor-de-landbouw-2717.pd Rapport PBL Planbureau voor de Leefomgeving, PBL-publicatienummer: 2717, 122 pagina's.

Wageningen UR (2012) Healthy living in a biobased society. library.wur.nl/ WebQuery/wurpubs/fulltext/237786 ISBN 978-94-6173-480-8, 70 pagina's.

Weber, M., en $\mathrm{H}$. Rohracher (2012) Legitimizing research, technology and innovation policies for transformative change: Combining insights from innovation systems and multi-level perspective in a comprehensive 'failures' framework. Research Policy 41(6): 1037-1047.

wetten.overheid.nl/BWBR0036748/2017-01-01

WUR, Wageningen University \& Research (2017) Metropolitan Solutions. www.wur.nl/nl/show-longread/Metropolitan-Solutions-longread.htm

WRR, Wetenschappelijke Raad voor het Regeringsbeleid (2014) Naar een voedselbeleid. www.wrr.nl/publicaties/rapporten/2014/10/02/naar-een-voedselbeleid Amsterdam: Amsterdam University Press / Wetenschappelijke Raad voor het Regeringsbeleid, 175 pagina's.

Geraadpleegde websites:

www.agrimatie.n

www.clo.nl

www.dutch-cuisine.n

www.duurzamezuivelketen.nl

$\overline{\text { www.ecosysteme.danone.com }}$

www.fnhri.eu

www.globalgap.org

www.mosameat.com

www.scrumcompany.n

www.sdgnederland.n

www.sustainabilityconsortium.org
(1) Een duurzamer en gezonder voedselsysteem

(2) Opgaven voor een duurzamer en gezonder voedselsysteem

(3) Vijf richtingen voor voedselsysteeminnovatie

(4) Systeeminnovatiebarrières

(5) Voedselsysteeminnovaties kansen in Nederland

Referenties 


\section{Auteur}

Anne-Charlotte Hoes

\section{Dank}

De beschouwingen van Hans Dagevos, Krijn Poppe, Gemma Tacken en Ruerd Ruben op een eerdere versie hebben deze publicatie verbeterd. Bedankt voor jullie bijdrage.

\section{Vormgeving en infographics}

Wageningen University \& Research, Communication Services Jan Hugo Nuijt

\section{Fotografie}

Enric Sala (p. 2)

Gea Hogeveen (p.11)

Cyril Hou/Shutterstock.com (p.15)

Overige fotografie is vermeld in de publicatie of is afkomstig van

Shutterstock

Dit onderzoek is uitgevoerd door Wageningen Economic Research in opdracht van en gefinancierd door het ministerie van Landbouw, Natuur en Voedselkwaliteit, in het kader van het Beleidsondersteunend onderzoeksthema. Projectnummer: 2282100265 DOI https://doi.org/10.18174/456111

De missie van Wageningen University \& Research is 'To explore the potential of nature to improve the quality of life'. Binnen Wageningen University \& Research bundelen Wageningen University en gespecialiseerde onderzoeksinstituten van Stichting Wageningen Research hun krachten om bij te dragen aan de oplossing van belangrijke vragen in het domein van gezonde voeding en leefomgeving. Met ongeveer 30 vestigingen, 5.000 medewerkers en 10.000 studenten behoort Wageningen University \& Research wereldwijd tot de aansprekende kennisinstellingen binnen haar domein. De integrale benadering van de vraagstukken en de samenwerking tussen verschillende disciplines vormen het hart van de unieke Wageningen aanpak.

\section{Copyright}

(C) 2018 Wageningen Economic Research (instituut binnen de rechtspersoon Stichting Wageningen Research)

Overname, verveelvoudiging of openbaarmaking van deze uitgave is toegestaan mits met duidelijke bronvermelding. Overname, verveelvoudiging of openbaarmaking is niet toegestaan voor commerciële doeleinden en/of geldelijk gewin. Overname, verveelvoudiging of openbaarmaking is niet toegestaan voor die gedeelten van deze uitgave waarvan duidelijk is dat de auteursrechten liggen bij derden en/of zijn voorbehouden.

\section{Aansprakelijkheid}

Wageningen Economic Research aanvaardt geen aansprakelijkheid voor eventuele schade voortvloeiend uit het gebruik van de resultaten van dit onderzoek of de toepassing van de adviezen. 